\title{
Immune Tumor Microenvironment in Breast Cancer and the Participation of Estrogen and Its Receptors in Cancer Physiopathology
}

\author{
Mariana Segovia-Mendoza and Jorge Morales-Montor * \\ Departamento de Inmunología, Instituto de Investigaciones Biomédicas, Universidad Nacional Autónoma de México, Mexico \\ City, Mexico
}

Breast cancer is characterized by cellular and molecular heterogeneity. Several molecular events are involved in controlling malignant cell processes. In this sense, there is an overriding importance to study the multiple cell alterations within this pathology. That the immune response can vary depending on sex is a widely identified fact. Steroid hormones and their receptors may regulate different functions and the responses of several subpopulations of the immune system. Few reports are focused on the function of estrogen receptors (ERs) on immune cells and their roles in different breast cancer

Edited by:

Daniela F. Quail,

McGill University, Canada

Reviewed by:

Luis De La Cruz-Merino,

Hospital Universitario Virgen Macarena, Spain

Mallikarjun Bidarimath,

Cornell University, United States

*Correspondence:

Jorge Morales-Montor

jmontor66@biomedicas.unam.mx

Specialty section:

This article was submitted to

Cancer Immunity and Immunotherapy,

a section of the journal

Frontiers in Immunology

Received: 30 November 2018

Accepted: 11 February 2019

Published: 01 March 2019

Citation:

Segovia-Mendoza M and

Morales-Montor J (2019) Immune

Tumor Microenvironment in Breast

Cancer and the Participation of Estrogen and Its Receptors in Cancer

Physiopathology.

Front. Immunol. 10:348.

doi: 10.3389/fimmu.2019.00348 subtypes. Thus, the aim of this review is to investigate the immune infiltrating tumor microenvironment and the prognosis conferred by it in different breast cancer subtypes, to discuss the current knowledge and to point out the roles of estrogen and its receptors on the infiltrating immune cells, as well as to identify how different immune subsets are modulated after anti-hormonal treatments in breast cancer patients.

Keywords: immune infiltration, breast cancer, estrogen receptor, estrogen receptor inhibitors, tumor microenvironment

\section{INTRODUCTION}

\section{Breast Cancer and the Microenvironment of Infiltrated Immune Cells}

Breast cancer is the most frequently diagnosed malignancy in women worldwide, and it represents the second most common cause of cancer deaths (1). Epidemiological studies have indicated that steroid sexual hormones play important roles in the initiation and progression of breast cancer. Other risk factors are also associated with this disease such as diet, ethnic differences, age, early menarche, not bearing children, having a first pregnancy at over 30 years of age, obesity, genetic mutations, exposure to oral contraceptives, consumption of alcohol or cigarettes, and environmental contaminants, among others. It is estimated that more than 1,000,000 women are diagnosed with breast cancer every year, and more than 410,000 will die from the disease $(2,3)$. The above indicates that breast cancer represents an important worldwide health problem.

On the other hand, breast cancer is a heterogeneous disease, which is traditionally classified into three phenotypes: luminal [estrogen receptor (ER) positive], human epidermal growth factor receptor type 2 (HER2)-positive, and triple negative (ER-negative/HER2-negative) (4). Moreover, breast cancer is characterized by a highly inflammatory microenvironment, which is supported by the infiltrating immune cells, cytokines, and growth factors $(5,6)$. In addition, immune infiltration 
of breast tumors has been shown to be related to clinical outcome through the modulation of treatment response. Breast tumors with immune infiltration are associated with different patterns based on ER presence; however, a common negative immune feature is that regulatory $\mathrm{T}$ cells ( $\mathrm{T}$ regs) are associated with poor prognosis in both ER-positive and ER-negative breast tumors, conferring an immunosuppresive environment $(7,8)$. Such a feature is a characteristic that highlights the importance of the immune tumor microenvironment in breast cancer.

With respect to other infiltrating immune cells in breast cancer phenotypes, a strong proportion of natural killer cells (NK) and neutrophils have been found in ER-positive breast tumors, while cytotoxic T cells $\left(\mathrm{TCD}^{+}\right)$as well as naïve and memory $\mathrm{T}$ cells $\left(\mathrm{TCD} 4^{+}\right)$are found in smaller proportions. Interestingly, eosinophils and monocytes are associated with a good response after chemotherapy, and B lymphocytes are also associated with good prognosis in this phenotype. Recently, activated mast cells have additionally been correlated with good prognosis (9). However, the presence of this population is still controversial (10). Moreover, in this phenotype, tumor-associated macrophages (TAMs) 1 and 2 and $\mathrm{T}$ reg lymphocytes displayed poor prognosis due to their inflammatory, immunosuppressive, and pro-tumorigenic roles (11-14). In ER-negative breast tumors, the major component of immune infiltration cells are T regs, TAM2, and activated mast cells, which are also associated with negative prognosis. In contrast, $\mathrm{TCD}^{+}{ }^{+}, \mathrm{TCD}^{+}{ }^{+}, \mathrm{B}$ lymphocytes, and dendritic cells (DCs) are related to better prognosis, but they are found in lower numbers and can be associated with a favorable response to neoadjuvant chemotherapy $(7,14-21)$. With respect to the HER2-positive breast cancer type, there are not many reports about the infiltrating immune mass. However, it is mainly represented by DCs, mast cells, $\gamma \delta \mathrm{T}$ lymphocytes, $\mathrm{T}$ regs and neutrophilsinterestingly, all of them confer poor prognosis, disease relapse, and metastasis in this phenotype (see Figure 1) (14, 22, 23).

This intra-tumoral immune pattern establishes a complex relationship between the heterogeneity of immune infiltrating

\footnotetext{
Abbreviations: BPA, bisphenol A; cAMP, cyclic adenosine monophosphate; CAT, catalase; CG, cathepsin G; Da, daltons; DAG, diacilglycerol; DCs, dendritic cells; DNA, deoxyribonucleic acid; E2, estradiol; ERK, extracellular signalregulated kinase; ER, estrogen receptor; EREs, estrogen response elements; G-CSF, granulocyte colony-stimulating factor; GFRs, growth factor receptors GPER1; GM-CSF, granulocyte macrophage colony stimulating factor; GPER1, G protein-coupled estrogen receptor 1; GSH-Px, glutathione peroxidase; GSTP, glutathione S-transferase P; HER2, epidermal growth factor receptor type II; IFN- $\gamma$, interferon-gamma; Ig, immunoglobulin; IL, interleukin; iNOS, inducible nitric oxide synthase; IRF4, interferon regulatory transcription factor 4; LPS, lipopolysaccharide; MCs, mast cells; MCP-1, monocyte chemo-attractant protein 1; MMPs, metalloproteinases; NE, neutrophil elastase; NETs, neutrophil extracellular traps; NF- $\kappa \mathrm{B}$, nuclear factor-B; NK, natural killer cells; NO, nitric oxide; PAMPs, pathogen-associated molecule patterns; PI-9, proteinase inhibitor 9; PI3K/AKT, phosphoinositide 3-kinase; PR3, proteinase 3; PTGS2, prostaglandinendoperoxide synthase; ROS, reactive oxygen species; SERM, selective estrogen receptor modulator; SOCS3, suppressor of cytokine signaling 3; SOD, superoxide dismutase; TAMs, tumor-associated macrophages; TET1, ten-eleven-translocation 5-methylcytosine dioxygenase; TCD4, helper T cells; TCD8, cytotoxic T cells; TGF$\beta$, tumor growth factor beta; TLRs, Toll-like receptors; TNF $\alpha$, tumor necrosis factor alpha; T regs, regulatory T cells; VEGF, vascular endothelial growth factor.
}

cells, the tumor phenotype, and the treatment response in breast cancer.

\section{ESTROGEN SIGNALING AND ESTROGEN EFFECTS IN BREAST CANCER CELLS}

Estradiol (17 $\beta$-estra-1,3,5 (10)-triene-3,17-diol) E2 is a steroid hormone produced by theca and a granulosa cell in the ovaries. E2 regulates several physiological and pathological processes, including cancer. Classical or genomic E2 signaling is mainly mediated by two isotypes of the receptor: $\operatorname{ER} \alpha$ and $\operatorname{ER} \beta$, both of which are nuclear transcription factors that bind to their specific ligand or several estrogens in general; and, subsequently, they form homo- or heterodimers that bind to estrogen response elements (EREs) contained in the promoter region of specific genes in order to activate or suppress their expression. These actions are mediated by the recruitment of distinct co-activators or co-repressors or through the interaction with other transcription factors (Figure 2) (24). E2 actions are also mediated by other non-classical pathways, known as ligand-independent $\mathrm{ER} \alpha$ signaling, by a membrane-anchored receptor called G protein-coupled estrogen receptor 1 (GPER1), in which target gene transcription occurs through second messengers and several transcription factors. Thus, GPER1 mediates the increase of different second messengers such as cyclic adenosine monophosphate (cAMP) and diacilglycerol (DAG) levels, mobilization of intracellular calcium $\left(\mathrm{Ca}^{2+}\right)$, and the activation of extracellular signal-regulated kinase (ERK)1/2 and the phosphoinositide 3-kinase (PI3K/AKT) pathways by the trans-activation of the different growth factor receptors (GFRs). Moreover, activation of GPER1 can induce the release of several growth factor ligands such as heregulin, which results in a direct activation of GFRs, depicted in Figure 2 (25-28). It is important to mention that different antagonists or ER inhibitors, such as ICI182,780 and tamoxifen, can mimic the effects of estradiol and induce GPER1 activation.

In breast cancer, E2 can act in different ways. For instance, in immortal cell lines of breast cancer, E2 via ER $\alpha$ signaling is seen to stimulate proliferation, while ER $\beta$ activation inhibited cell proliferation and promoted apoptosis $(29,30)$. Interestingly, estrogen can also undergo several metabolic processes, and its metabolites exert genotoxic effects that contribute to the development of breast cancer through adduct DNA formation (31-33). Many reports on the effects of E2 in breast cancer cells have reported the transcriptional modulation of different genes that are affected; among which are proliferation regulators, growth factors, cell cycle, and apoptotic modulators $(29,34,35)$.

Importantly, both classic and membrane ERs have been implicated in several effects of immunity and autoimmunity (36, 37). It is known that the immune system shows remarkable sexdifferential responses; thus, this fact potentially suggests that sex hormones such as estrogens address these events. Following this, many reports mention that women respond more aggressively to self-antigens, being more susceptible to autoimmune diseases through of the activation of ER signaling (38). In general, ERs participate in many immune system functions-ER $\alpha$ has been 


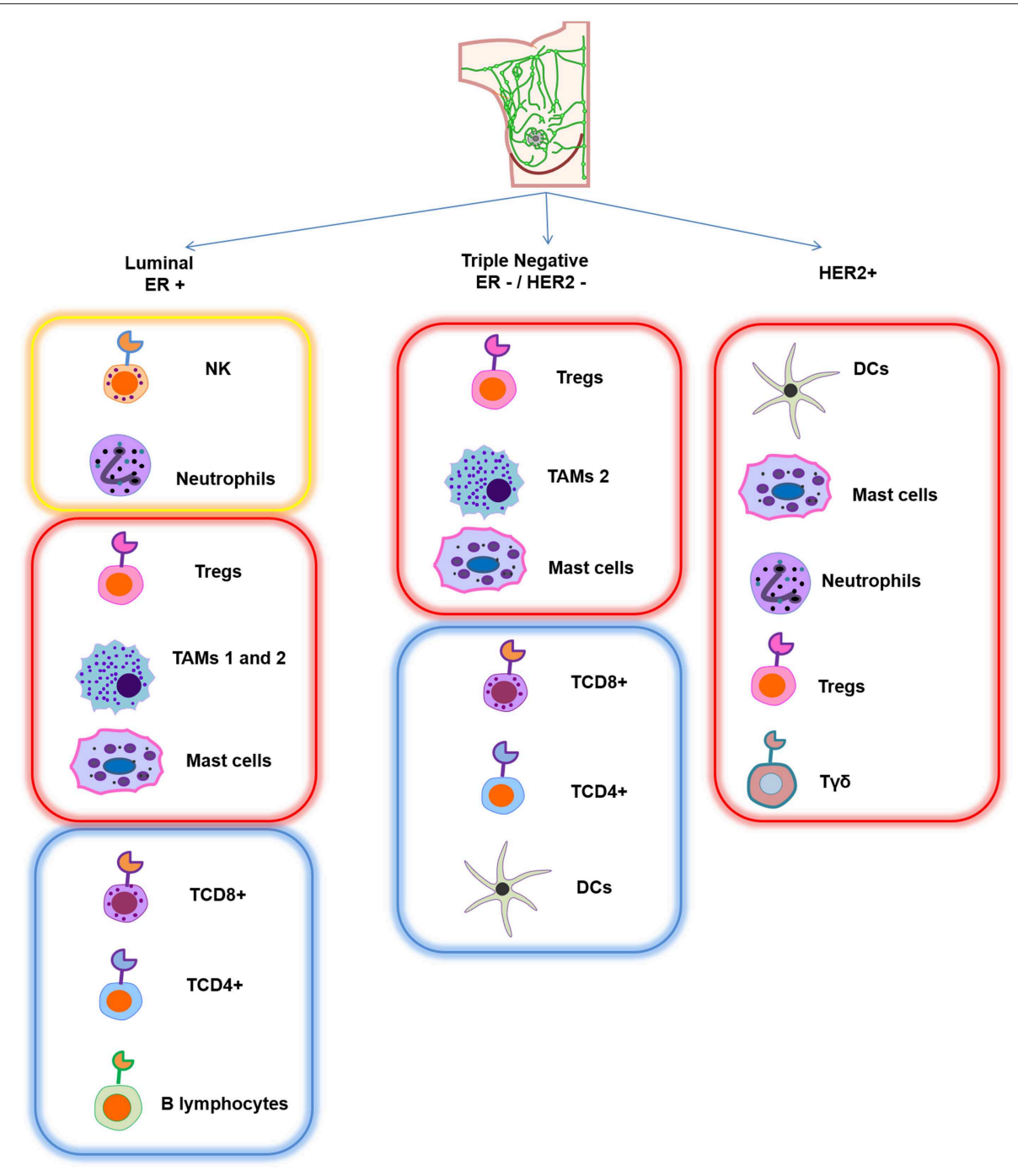

FIGURE 1 | Schematic representation of the main infiltrating immune cell pattern in different breast cancer subtypes. Each subtype has a different composition of immune cells. Yellow frame represents strong presence of specific immune cells that confer good prognosis, red frame indicates that this infiltrating signature is associated with poor prognosis, and blue frame corresponds to a lower proportion of immune cells, which is also associated with good prognosis.

related to spleen and thymus function while ER $\beta$ is important for bone marrow functions (24). Both types of ERs are expressed on innate and adaptive immune system cells, indicating an important role for this hormone and its receptor signaling regarding correct immune performance (39).

We describe below the modulation of the most common tumor-infiltrating immune cells by estradiol action upon binding to its receptors in these immune cells of the tumor microenvironment.

\section{ESTROGEN EFFECTS ON IMMUNE SYSTEM CELLS}

\section{ER in Dendritic Cells (DCs)}

DCs are involved in several processes such as immune tolerance, autoimmunity, stimulation, and differentiation of naïve $\mathrm{T}$ cells. They are considered as potent antigen presenting cells (APCs) and are mainly activated by stress or damage signs from pathogens that are recognized mainly by Toll-like receptors (TLRs). Following their stimulation via TLRs, DCs secrete proinflammatory cytokines to stimulate $\mathrm{T}$ lymphocytes and initiate innate immune response. In this sense, ER participates in the favoring of DC function. These cells contain the presence of ERs; when its ligand binds to ERs in these cells it can trigger migration and activation processes. In addition, in mouse in vitro models of DCs, estrogen can induce differentiation, survival, and increase the expression of co-stimulatory molecules (39). It has been reported that pre-treatment of E2 in co-cultures of mature DCs with T cells resulted in the stimulation of $\mathrm{T}$ cell proliferation (40). Besides, E2 up-regulates the expression and secretion of different pro-inflammatory cytokines and chemokines such as tumor necrosis factor alpha (TNF $\alpha$ ), interleukin (IL)-6, CXCL8 (IL-8), and monocyte chemo-attractant protein 1 (MCP-1) (40). This concept can be directly related to the improvement 


\section{Genomic pathway}

Non-genomic pathway

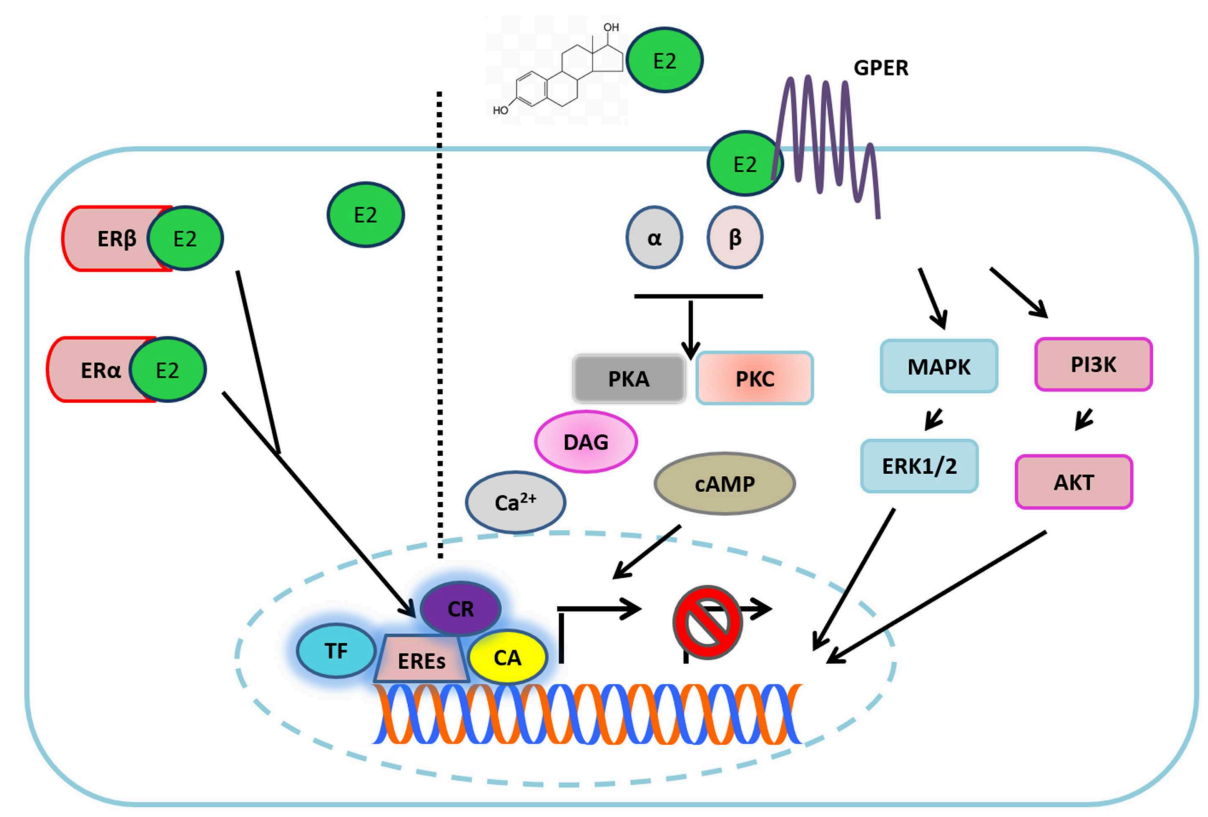

FIGURE 2 | Estradiol signaling. Estradiol (E2) can bind to its different receptors to activate the genomic pathway or the non-genomic pathways. In the first one, E2 binding to $E R \alpha$ and $E R \beta$, each complex is directed to the nucleus where it joins with EREs in the DNA, recruiting different transcription factors (TF), co-activators (CA), or co-repressors (CR) in order to activate or suppress the transcription of target genes. In the non-genomic pathway, E2 binds to GPR30, triggering the activation of G proteins. The above turns out in the increase of different second messengers (CAMP, $\mathrm{Ca}^{2+}$, DAG). Additionally, E2 can activate different growth factor receptor (GFR) activity through the non-genomic pathway, which results in the activation of different downstream signaling pathways (MAPK and PI3K) and in the release of different ligands of GFRs.

of DCs' capability to mediate the presentation of self and foreign antigens, and, potentially because of this, the immune system response against tumors is better in early stages of the disease. Nevertheless, the presentation process is disrupted by E2, since after hormone exposure, production of INF- $\gamma$ and IL2 is decremented in mature DCs (41). This suggests that the effects of E2 in DCs depend on their maturation stage. Thus, it would be interesting to determine the degree and phenotype of DC maturation in tumors. In addition, differentiation of functional DCs from bone marrow can also be modulated by this hormone since it favors their migration to lymph nodes, an effect that was reverted with the use of specific ER $\alpha$ antagonist (ICI 182,780) (42-44). Supporting this notion, E2 induces myeloid DC differentiation through the activation of two inflammatoryrelated proteins, the interferon regulatory transcription factor 4 (IRF4) and the participation of granulocyte macrophage colony stimulating factor (GM-CSF). Interestingly, it was reported that the exacerbated activation of these two factors by E2 at some point can lead to a tolerogenic phenotype for DCs (45). The association of $\mathrm{ER} \alpha$ with other proteins such as thiolase and glutathione S-transferase P (GSTP) is also linked with DC differentiation. In addition to this, metabolic function, several growth factors, and accessory proteins in bone marrow derived from mice DCs are also affected. On the contrary, the absence of GSTP enhanced DCs' metabolism, their proliferative and differentiation rates, and their effector functions (46). It is important to note that not only does E2 have effects in DCs, an estradiol metabolite, estriol also generated tolerogenic DCs in an in vivo model that protects against autoimmunity (47). The above highlights the need to monitor the effects of ER inhibitors on different immune cell functions, favoring not only the inhibition of cancer cells but also the migration of the immune cells to lymph organs or avoiding their anergic phenotype.

\section{ER in Macrophages (Mø)}

Macrophages are a fundamental part of the innate defense mechanisms against foreign pathogens, and they can promote specific immunity by inducing $\mathrm{T}$ cell recruitment and activation. Their role is essential for triggering adaptive immune response. Macrophages collaborate with $\mathrm{T}$ and $\mathrm{B}$ cells based on the release of cytokines, chemokines, and reactive radicals, among other proteins. Despite this fact, their presence within the tumor microenvironment has been associated with enhanced tumor progression and promotion of cancer cell growth, angiogenesis, and immunosuppression $(11,48)$.

Several articles have reported the presence of ER in monocytes and macrophage precursor cells $(49,50)$, that the expression of this hormone receptor varies between stages of differentiation, and that monocyte expresses ER $\beta$ while macrophages express $\mathrm{ER} \alpha$ (51). Recently, however, both receptors have been found in macrophages (52). E2 treatment has been shown to modulate different macrophage actions and their metabolism; for example, 
it is well-known that production of nitric oxide (NO) into the macrophages allows them to exert antimicrobial and antitumor actions (53). Related to this concept, hormone treatment stimulated NO release in human peripheral monocytes and in a murine macrophage cell line via GPER activation coupled with intracellular calcium influx $(54,55)$. In line with this, stimulation with LPS in isolated peritoneal macrophages from young female rats resulted in elevated NO release; this effect was not observed in macrophages derived from the middleaged animals, where circulating E2 levels were diminished (56). Moreover, macrophages produce and use arachidonic acid and its different metabolites for the recognition of pathogens and to enhance or suppress inflammatory response (57). E2 has been shown to modulate the lipid metabolism of macrophages since it elicits an increase of arachidonic acid release and prostaglandin E2 production (a derivative of arachidonic acid) in human monocytic cell lines (58). In addition, the phagocytic activity of macrophages is performed in part by reactive oxygen species (ROS) - which cause DNA or cell membrane damage-and the interplay between intracellular ROS and antioxidant enzymes such as superoxide dismutase (SOD), catalase (CAT), and glutathione peroxidase (GSH-Px) is important in the macrophage phagocytic function, activation, differentiation, and recruitment process (59). In this context, it has been reported that E2 administration in rats modulated CAT activity in ex vivo macrophages (60). Part of the bacterial killing mechanism of macrophages induced by LPS is the activation of metalloproteinases (MMPs); gene expression of MMP-9 especially was dramatically reduced after E2 treatment in rat cell lines of macrophagic origin, and this effect was blocked with ICI 182,720 treatment (61). This hormone also modulates macrophage survival, and this effect was reported in an in vitro culture of human macrophages where E2 treatment induced the anti-apoptotic protein $\mathrm{Bcl}-2$, action mediated by the modulation of the intracellular $\mathrm{Ca}^{+2}$ concentration, the activation of protein kinase C, and ERK phosphorylation (62, 63). Furthermore, macrophages can recognize distinct pathogenassociated molecule patterns (PAMPs) which contributes to activating several signaling cascades and diverse cytokines and chemokines (64). E2 via ER $\alpha$ reduced gene and protein expression of the pro-inflammatory IL- 8 in monocytes previously challenged by LPS (65). The modulation of this chemokine impacts not only the macrophage's function but also the neutrophil's recruitment to inflammation sites, mediating pathogen clearance (66). E2 can also modulate other functional macrophage cytokines; its treatment decreased IL-6, TNF- $\alpha$, and IL- $1 \beta$ expression in whole blood cultures derived from healthy postmenopausal women, in bone marrow cell cultures, and in ex vivo rat macrophages $(56,67-70)$. The modulation of these cytokines was confirmed to be an E2-dependent effect, according to the opposite event found in these cells when they were treated with ICI 182,780 (69). A similar result from E2 treatment related to the decreased expression of the TNF- $\alpha$ gene was reported in an ER-positive murine monocytic cell line through of the down-regulation of Jun $\mathrm{NH}$ (2)-terminal kinase activity, with a consequent decrease of AP-1 transcription factor, affecting TNF$\alpha$ transcription (71). In addition, E2 modulates the macrophage's activation (72), which is mainly classified into two categories: classical activation (macrophages kill microbes and act as antitumor effector cells), which is promoted by IFN- $\gamma$, TNF- $\alpha$, and TH2-related cytokines or alternative activation (macrophages lay down extracellular matrix components to promote wound healing, angiogenesis, and sustain tumor progression). This type of macrophage activation is promoted by TH1 cytokines, being an IL-4/IL-13-dependent mechanism (73). The effect of this hormone in macrophage activation was clearly observed in a murine wound healing model in ovariectomized mice. In this sense, macrophages coming from ovariectomized animals show preferentially a classical activation. In addition, the gene expression of two alternative activation macrophages markers (Fizz1 and Ym1) was reduced, and the ovariectomized mice also presented a reduction in both macrophage numbers in the wound area and the inflammatory environment through the reduction of monocyte-associated TNF- $\alpha$ secretion as compared with the intact group. In contrast, E2 supplementation in ovariectomized mice restored the expression of both markers, leading to alternative macrophage activation, wound repair, remodeling, and angiogenesis (72). Furthermore, the alternative macrophage activation promoted by E2 has been documented in other assays. With respect to this notion, the gene expression of arginase 1, another established alternative activation macrophage marker, was up-regulated with $\mathrm{ER} \alpha$ agonist treatment in an in vitro culture of bone marrow-derived macrophages (74). This work also evaluated the role of E2 in wildtype or in mice with $\mathrm{ER} \alpha$ and inflammatory gene deletion (LysM-ER $\alpha$ ) subjected to incisional wounds with a subsequent exogenous E2 replacement. Of note, in the absence of the hormone, healing was delayed (74) as has been previously reported in an ovariectomized wildtype mouse model (72). However, the hormone treatment revealed increased recovery in healing response, whereas in $\mathrm{ER} \alpha$ knockout mice it resulted in a marked healing delay. The above highlights the role of estradiol-ER $\alpha$ action in the induction of alternative macrophage activation (74). Additionally, the role of E2 in favoring alternative macrophage activation was corroborated in an in vitro and ex vivo study on human blood-derived macrophages. In fact, classical lipopolysaccharide (LPS)/IFN- $\gamma$ stimulus on un-polarized macrophages induced the down-regulation of two markers of alternative activation (CD163 and CD206); these effects were avoided through treatment via the modulation of $\mathrm{NF} \kappa \mathrm{B}$ transcription factor (75). Interestingly, much evidence supports the notion that macrophages, especially alternatively activated macrophages, shape immune tumor infiltration and have influence in high vascular grade associated with metastasis (76-79). In this sense, breast cancer phenotype can also regulate the type of infiltrating macrophage phenotype (80). Current evidence suggests that this population of macrophages regulates at the same time $E R \alpha$ expression in an epigenetic manner through the modulation of a DNA hydroxymethylation marker, ten-eleventranslocation 5-methylcytosine dioxygenase (TET1). The above was demonstrated in co-cultures of endometrial cancer cells with alternatively activated macrophages, with the results showing that alternatively activated macrophages enhanced both E2driven endometrial cancer cell proliferation and up-regulation in 
ER $\alpha$ expression, a mechanism dependent on IL-17A expression (81). The above highlights the importance of the interplay among sex steroids, the immune system, and tumor progression.

\section{ER in Mast Cells}

Mast cells (MCs) are tissue-resident immune cells that form part of the innate immune system. They are commonly associated with allergic reactions and parasitic infections. These cells are characterized by the presence of granules loaded with different inflammatory mediators that they release depending on the time and the type of stimulus (82). Additionally, secretion of serine proteases such as tryptase or chymase define what phenotype of the mast cell will be activated, which means that mucosal mast cells produce tryptase and the connective tissue mast cells secrete tryptase, chymase, and carboxypeptidases (83). These enzymesin conjunction with the release of IL-8, tumor growth factor beta (TGF- $\beta$ ), and TNF- $\alpha$-have been associated with angiogenesis trough vascular endothelial growth factor (VEGF) and MMP modulation in different breast cancer phenotypes $(9,84)$. Mast cells can be activated by the direct recognition of pathogenassociated molecular patterns (PAMPs) or by immunoglobulins and immunoglobulin E receptor (Fc $\in \mathrm{RI}$ ) interaction; both cases result in the release of different molecules from their granules, recruiting different immune cells.

On the other hand, several studies have reported the presence of ER $\alpha$ but not ER $\beta$ in mast cells; however, it was recently described that these cells have the presence of both nuclear receptors (85-88). In this sense, treatment of E2 or an endocrine disrupting compound such as bisphenol A has been demonstrated to induce the release of histamine (an important biomolecule involved in allergic reactions) from rat mast cells in a concentration-dependent manner (89). Of note, the histamine release is also important in breast cancer promotion since this protein or its receptors (H3R and H4R) have been associated with the induction of breast cancer cell proliferation and migration. Importantly, these molecules have been identified to a greater extent in breast tumor samples as compared with non-tumor samples (90). The above suggests that the inhibition of this molecule could result in an interesting target in this disease. E2 has an important role in inducing the release of asthma mediators such as leukotriene and $\beta$-hexosaminidase in a rat mast cell line. The release of $\beta$-hexosaminidase has also been described in both the human mast cell line and in a primary culture (non-transformed) of mast cells. This action was blocked with the addition of tamoxifen or ICI 182,780, demonstrating that $\mathrm{ER} \alpha$ is responsible for these actions $(89,91,92)$. In relation to breast cancer progression, tryptase release from mast cells has been closely associated with an increased number of carcinomaassociated fibroblasts in breast tumor samples, favoring the tissue remodeling and angiogenesis (93). Related to this, E2 upregulates tryptase secretion in the human mast cell line HMC-1 (88), assuming that it induces the degranulation of these cells. In addition, $\mathrm{E} 2$ in an ex vivo model induces the expression of two chemokine receptors (CCR4 and CCR5), which are implicated in the migration of periphery mast cells to the uterus $(88,94)$. The above highlights the effects of $\mathrm{E} 2$ in mast cell function with the purpose of favoring breast cancer progression. On the other hand, there are few reports with respect to E2 function by the non-genomic pathway in mast cells. In this regard, it has been shown that estradiol induces the release of intracellular calcium, which is important for degranulation and leukotriene synthesis in mast cells (95). Recently, the role of mast cells in breast cancer has been largely studied (10); however, many of their functions and components in their granules in relation with breast cancer progression are still little addressed, and this makes them an important population for study in the cancer microenvironment.

\section{ER in Neutrophils}

Neutrophils, which are other fundamental pathogen-fighting immune cells, constitute the first line of host defense. They can be recruited to infection sites and eliminate microbes by classical phagocytosis or degranulation, and they also produce ROS, release antimicrobial peptides, or expel their nuclear content in order to form neutrophil extracellular traps (NETs) $(96,97)$. Neutrophils collaborate with other immune cells such as macrophages or DCs and secrete many chemokines and cytokines that regulate the immune response (98). It has been described that neutrophils as well as other immune cells present both nuclear receptors (99). In this regard, E2 through $\mathrm{ER} \alpha$ binding has been shown to regulate neutrophil survival, function, and number. E2 exposure delayed apoptosis in human neutrophils, and this effect was correlated with a significant decrease in active caspase 3 protein expression and was reverted by ICI 182,780 treatment (100). This represents a possible explanation of sexual dimorphism, being that neutrophil number differs between men and women (101). One effect of E2 on the function of neutrophils is that it enhances NO production and nitric oxide synthase, demonstrated previously in human neutrophils $(102,103)$. Additionally, neutrophils secrete several serine proteases (NSPs), including neutrophil elastase (NE), proteinase 3 (PR3), and cathepsin G (CG), which are essential for the elimination of infectious agents and the modulation of inflammation (104). Neutrophils derived from splenocytes of mice administered with E2 showed incrementation of NE, PR3, and CG in gene and protein expression as compared with placebo-treated mice. Moreover, E2 administration in these mice increased the number of neutrophils in different lymphoid tissues (splenocytes, peripheral blood, and bone marrow) and the gene and protein expression of myeloperosidase, a major component of neutrophil granules (105). E2 via ER $\alpha$ modulated inflammation, and the actions mentioned above were associated with an autoimmune disease as an increase in neutrophil number and NSPs were found in mice with lupus (105). Moreover, G1GPER1 activation also participates in neutrophil polarization (analogous concept of macrophage activation) (106), promoting the gene expression of the pro-inflammatory phenotype (N2) and its lifespan, actions mediated by the activation of the cAMP/PKA/CREB, MAPK, and p38 signaling pathways (107). This work also shows that IL-1 $\beta$, IL- 8 , the prostaglandinendoperoxide synthase (PTGS2), the suppressor of cytokine signaling 3 (SOCS3), and granulocyte colony-stimulating factor (G-CSF) gene expression, were enhanced after stimulation of G1GPER1 in a dose-dependent manner. Additionally, the release of IL-8 was significantly increased as compared with non-treated 
human neutrophils and with neutrophils stimulated with LPS. Furthermore, this hormone-receptor interaction up-regulated the surface expression of two markers of neutrophil activation (CD11b and CD62L) (107), supporting the notion that G1GPER1 interaction is responsible for IL-8 neutrophil release. Other work proved that $17 \beta$-estradiol-ER $\alpha$ did not induce the release of this chemokine; in fact, the estradiol treatment had the opposite effect in the release of this chemokine in human neutrophils pre-stimulated with LPS (108). In addition, this classical activation may participate in the attenuation of neutrophil activation. E2 reduced the shedding of a surface adhesion neutrophil molecule (CD62L or selectin) (108), which is normally implicated in diapedesis at sites of tissue injury and inflammation (109). Also, E2 treatment blocked the neutrophil chemotaxis promoted by IL- 8 , and the generation of superoxide anion by neutrophils was diminished with this hormone treatment $(108,110,111)$, affecting their host defense function (112).

It is well-known that a certain type of breast cancer is dependent on E2 action; coupled with this notion, this hormone can promote inflammation through the induction of neutrophil infiltration and the expression of pro-tumoral cytokines/chemokines and tissue-remodeling enzymes in mammary neutrophils (113). In a mammary involution mice model, E2 administration induced mammary neutrophil infiltration and neutrophil pro-tumoral activity signature, as at least 10 inflammatory genes were up-regulated in mammary resident cells; interestingly, neutrophil depletion reversed the expression pattern of these inflammatory genes. Moreover, in this mammary involution mice model, the mice were administrated with E2 and injected with a triple negative breast cell line (4T1). Again, the hormone treatment induced mammary neutrophil infiltration-however, neutrophil depletion with a specific antibody resulted in the marked abolition of estrogen-induced mammary tumor growth (113). The mammary neutrophil recruitment induced by this hormone was observed in other in vitro and in vivo breast cancer research, in which it promoted N2-neutrophil polarization, correlated with the overexpression of integrin LFA- 1 and TGF- $\beta$, intra- and extravasation and trans-endothelial breast cancer cell migration, and with major breast tumor growth; this last effect was reversed by ICI 182,780 treatment. In fact, E2 treatment transformed a non-metastatic breast cancer cell line into one that was metastatic-associated in the presence of neutrophils (114). The previous observations provide the presence of mammary neutrophils and its activitywhich are importantly regulated by E2-with a significance regarding cancer progression.

\section{ER in NK Cells}

NK cells are central components of the innate immunity and they participate in preventing and controlling infections, tumor growth, and metastasis (115). Usually, in tumors there is a downregulation of self-ligands and expression of stress-induced ligands which can be recognized by NK cells (116). Their activation also leads to secretion of stimulatory cytokines and chemokines such as IFN- $\gamma$, TNF- $\alpha$, GM-CSF, MIP1- $\alpha$, and RANTES, which participate in the stimulation of the adaptive immune system. Moreover, their biological importance lies in their ability to exert a cellular cytolytic effect through the liberation of granzymes and perforin (117).

Since the 1990s, it has been known that E2 causes a reduction in NK cell cytotoxic activity in mice models in a dose-dependent manner $(118,119)$. This data was confirmed when the hormone was administered in postmenopausal and premenopausal women, resulting in a reduction in NK cell activity (120). In fact, the use of oral contraceptives, which bind to sex steroid receptors, has been associated with changes in NK cytotoxic activity and with an increase in infections (121). Interestingly, the suppressive effect of E2 on the NK cells was attributed to the enhancement of metastasis in a fibrosarcoma and melanoma cell model, where immunosuppressed mice treated with this hormone also exhibited deficient NK cell activity and increased susceptibility to develop metastasis of allogeneic tumor cells (122). Additionally, synthetic non-steroidal estrogens such as diethylstilbestrol showed the same effects regarding inhibitory NK cell activity and the mice's susceptibility to generating tumors derived from this NK cellular inhibition. Of note, NK inhibitory activity was dramatically affected with only neonatal administration of diethylstilbestrol into the mice (123). On the other hand, it has been described that E2 can induce or suppress NK cell activity in mice, with the actions being dependent on time. At short time intervals it acts in a stimulating way, and at long time intervals it suppresses NK cell activity (124). Estrogen can also inhibit NK cell-mediated apoptosis due to the fact that this hormone induced a granzyme inhibitor, named proteinase inhibitor 9 (PI-9) (125). Today, there are few reports that evaluate the effects of E2 in NK cells. However, it is known that the reduction of their activity is related to the promotion of tumor growth (126); therefore, NK cells might be considered as a target for immune therapies in order to avoid the estrogen-mediated increase in breast tumor incidence.

\section{ER in B Cells}

B lymphocytes are part of the adaptive immune system that is specialized in antibody production, which is part of humoral immunity (127). It has been described that B lymphocytes have the expression of both nuclear ERs in all B cell subsets $(39,128)$. In this sense, E2 has stimulatory effects on Bdifferentiated lymphocytes derived from human PBMCs. It increased immunoglobulin (Ig) G and IgM production in a dosedependent manner, and this effect was enhanced by the addition of IL-10, an anti-inflammatory cytokine, to B cells previously treated with E2 (129), and the above becomes relevant in an autoimmune context. The stimulatory effect of E2 on antibody titers has been observed since the 1980s in in vitro studies and in the serum of rats administered with this hormone, where an increase in IgM antibodies was reported $(130,131)$. Of note, it has been reported that IgMs have a direct cytotoxic effect on transformed cells through the activation of the complement pathway $(132,133)$. This is relevant since the increases on IgMs levels due to E2 exposure are important for breast cancer suppression. Besides, they also might serve as diagnostic indicators of the phenotype or stage of this pathology due to the fact that they are well-correlated with the clinical score and 
disease spread of breast cancer patients (134); however, more studies are necessary to confirm this fact. Added to that, E2 through the $\mathrm{ER} \alpha$ pathway also impacts the activation and survival of $B$ cells through the modulation of several genes. These effects were observed in splenic B cells derived from ovariectomized mice (or not) administered with it. Interestingly, these results were reverted in mice treated with ICI 182,780 (128). Regarding the effects of GPR30 on B lymphocytes, some reports have mentioned that different chemokines can activate it, triggering different roles of $\mathrm{B}$ subsets such as migration, chemotaxis, proliferation, and apoptosis, among others. In fact, this receptor has been correlated with different $\mathrm{B}$ cell malignancies such as leukemia and lymphomas $(135,136)$. Nevertheless, more information or mechanisms of action related to this topic would be interesting in relation to the pathogenesis of breast cancer.

\section{ER in TCD4 ${ }^{+}$and TCD8 ${ }^{+}$Cells}

Lymphocytes have important roles in immune protection; traditionally, these cells are divided into two subtypes, TCD4 ${ }^{+}$ and $\mathrm{TCD}^{+}$. The first subtype can help B cells to produce antibodies, in order to induce immune response through activation of macrophages and recruitment of different immune cells to specific sites with inflammation. The second type is important for defense against cellular pathogens, among other functions. These immune populations can contribute to attenuate inflammation, production of antibodies, and protection of pathogens (137). Based on the different cytokine secretion profiles, $\mathrm{TCD}^{+}$is divided into different subsetsfor instance, T helper (Th) 1 and Th2. Th1 is characterized by secretion of INF- $\gamma$, IL-2, IL-12, and TNF $\alpha$, which are cytokines that stimulate macrophages' functions and cellular response; meanwhile, Th2 cells secrete IL-4, IL-5, IL-6, and IL-10, which are important cytokines for $\mathrm{B}$ cell antibody production and humoral response.

It has been described that E2 affects the size, maturation, and development of $\mathrm{T}$ cells, a process known as thymic atrophy (37, 138), and this effect is mainly caused by ER $\alpha$ signaling (139). Moreover, it can also influence the expression of the phenotype of $\mathrm{CD}^{+} / \mathrm{CD}^{+} \mathrm{T}$ cells and their subsets' functions (140), and it also contributes to the development of other $\mathrm{T}$ cell subtypes from the lymph nodes, such as Th17 cells (141). Interestingly, the proliferation and generation of active $\mathrm{T}$ cells are governed by different metabolic glycolytic demands (142). In this sense, the orphan nuclear hormone receptor, estrogenrelated receptor- $\alpha(E R R \alpha)$, is a key regulator that supports $T$ cell functions, since the inhibition of ERR $\alpha$ decreased several glycolytic genes implicated in inflammatory cytokine production and $\mathrm{T}$ cell proliferation in an in vitro and in an experimental autoimmune encephalomyelitis mouse model, and a similar effect was found in ERR $\alpha$-deficient T cells (143). Several studies have demonstrated that E2 modulates IFN $\gamma$-secretion of Th1 cells in both human and mice cells, which is potentially mediated by direct interaction of ER with its EREs in the promoter region of the IFN $\gamma$ gene $(38,144,145)$. This cytokine has a pivotal role against intracellular infections as well as autoimmune and inflammatory disorders. Furthermore, E2 inhibits the production of Th1 pro-inflammatory cytokines such as IL-2, IL-12, IFN- $\gamma$, and $\mathrm{TNF} \alpha$ (146). In accordance with this notion, the decline of ovarian function related to menopausal state in women and reduction in the production of this hormone have been associated with an increment in pro-inflammatory cytokine production (147). In line with that, Th1-related cytokine levels such as IL-2 and IFN- $\gamma$ were augmented in postmenopausal women, and hormone replacement therapy in this population caused a significant decrease of these cytokines (148). On the other hand, the effects of E2 in Th2 cells are related to the increment of antiinflammatory cytokines such as IL-10, IL-4, and TGF- $\beta$ (146, 149). In addition, IL-4 incrementation has been correlated with the increase of an essential Th2 transcription factor (GATA-3) (150). Interestingly, E2 administration in a mammary involution mice model diminished $\mathrm{CD}^{+}{ }^{+}$and $\mathrm{CD}^{+} \mathrm{T}$ cells in mammary tissue, highlighting the effects of this hormone on the function of these immune cells' type (113).

\section{ER in Regulatory T Cells (Tregs)}

Tregs are involved in self-tolerance, suppression of immune cell functions, down-regulation of self-reactive lymphocyte action, and prevention of transplant rejection through activation of a lineage-specific transcription factor that governs Treg development, differentiation, maintenance, and functionforkhead/winged helix transcription factor (FoxP3) (151). The T regs' immunosuppressive $\mathrm{T}$ cell inflammatory activity includes IL-10 secretion and the induction of programmed cell death 1 receptor $(\mathrm{PD}-1)(137,152)$. In breast cancer, these cells are associated with a high rate of relapse and with favoring the tumor microenvironment $(7,16)$.

E2 in vitro and in vivo mouse models have been shown to induce the gene expression of FoxP3 and IL-10. These effects were reversed with the treatment ICI $182,780(153,154)$. It also modulates the Tregs' inhibitory capacity, since estradiol treatment increased intracellular PD-1 levels in Tregs coming from splenocytes of wildtype mice, whereas an opposite effect was seen in ER knockout mice (155). E2 treatment has also been shown to promote the proliferation and the number of human Tregs. In addition, it favors the change of $\mathrm{CD} 4^{+}, \mathrm{CD} 25^{-}$cells to a $\mathrm{CD} 4^{+}, \mathrm{CD} 25^{+}$Treg phenotype (156). Interestingly, a recent work demonstrated that infiltrating Tregs derived from human cervical cancer contain elevated levels of estrogen. Additionally, E2 through ER $\alpha$ signaling binds in the EREs of the Tregs' FoxP3 promoter. In this way, a loop is formed and leads to the activation of FoxP3 activity (157). As in other works, ICI 182,780 treatment reverted effects of E2 in Tregs and resulted in the ablation of FoxP3 protein expression and a decrease in TGF- $\beta$ secretion (157). Another study supports the notion that in addition to ER $\alpha$ signaling, GPER with the estrogenic small molecule (G-1) is critical for the expansion of Tregs and the induction of the Foxp3 protein in ex vivo cultures of purified $\mathrm{TCD}^{+}$mouse cells. In addition, G-1-GPER activation was able to maintain the Tregs' phenotype and to induce the expression of two proteins implicated in the control of immune homeostasis, PD-1, and cytotoxic T lymphocyte-associated protein 4 (CTLA4) in the presence of Th17 cytokine inflammatory polarization conditions (158). It has been described that Tregs secrete immunomodulatory cytokines such as TGF- $\beta$ and IL-10 (159). 


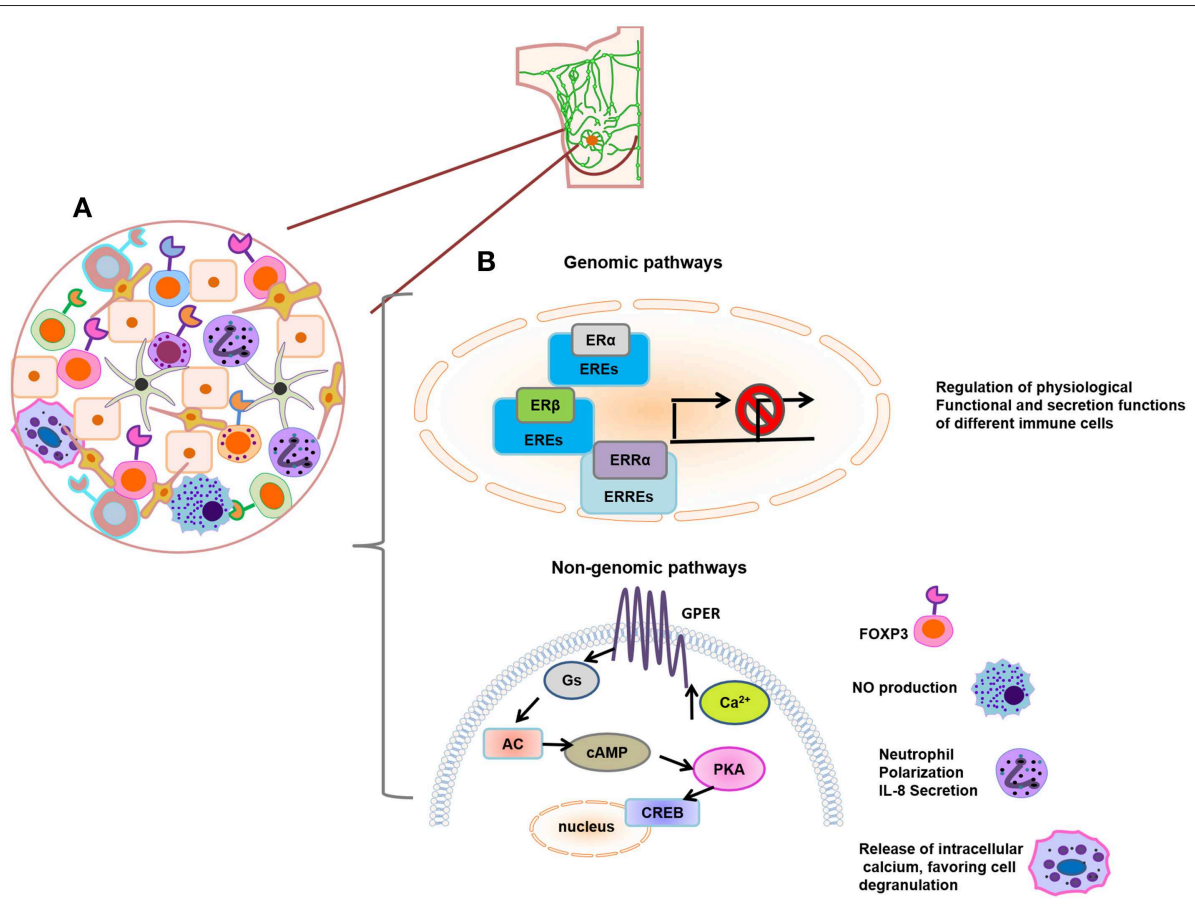

FIGURE 3 | (A) Schematic representation of immune infiltrating tumor cells. (B) Genomic and non-genomic estrogen pathways on immune cells. Estrogen regulates the physiological, functional, and secretion actions of different immune cells; these effects are mainly studied by the activation of genomic pathways such as ER $\alpha$, $E R \beta$, or ERR $\alpha$. In addition, little effects of Tregs (increase of Foxp3 expression), macrophages (NO production), neutrophils (neutrophil polarization and IL-8 secretion), and mast cells (mobilization of intracellular calcium, favoring cell degranulation) have been described by the action of non-genomic pathway.

This cytokine secretion pattern was favored with E2 treatment in Treg cells isolated from peripheral blood mononuclear cells (PBMCs) of healthy women (160). The previous data highlight the fundamental role of the estradiol-ER $\alpha$ / G1-GPER pathway in Treg physiology.

The estrogen pathways on immune cells studied in the basal condition described above are illustrated in Figure 3, which highlights that few reports have evaluated the effects of Tregs, macrophages, neutrophils, and mast cells mediated by nongenomic pathways. It also aims to represent how immune infiltration is found in breast cancer. In addition, Table 1 summarizes the effects of estrogen on the immune cells that we described in the previous section.

\section{REGULATION OF IMMUNE CELL FUNCTIONS BY ER INHIBITORS TREATMENT IN BREAST CANCER PATIENTS}

It is widely known and accepted that the use of inhibitors of ER in the treatment of patients with estrogen-positive breast cancer has offered high survival rates (161). However, their use in other breast cancer phenotypes and their effects on the immune system cells in clinical stages have not been addressed.

In the previous section, we described in vitro and in vivo data that clearly show how the tumor infiltrating immune cells could play an important role in the development, progression, and response of breast cancer through ER signaling activation. However, they also encourage focusing on the modulation of their antitumor functions with ER inhibitors. In this regard, few studies have reported the effect of ER inhibitors on immune infiltrating breast tumor cell functions in clinical phases. As we described previously, Tregs have been found to be up-modulated in breast tumors, and a high number of these cells were present in high-grade ER-negative breast cancer patients. Also, they were associated with ER-positive breast tumors identified with high-risk patients $(7,162)$. It is known that Tregs give valuable information about breast cancer prognosis and progression, since a high number of Tregs can identify patients at risk of relapse after 5 years. Nevertheless, there was no relationship between the number of Tregs and the type of therapy that patients received (7). Interestingly, in 2009, Generali et al. reported that the number of Tregs was significantly decreased in patients who received an aromatase inhibitor treatment alone (letrozole) and in combination with an antineoplastic agent (letrozole + cyclophosphamide) (163). Another in vivo model reported that ICI 182,780 could reverse the estradiol actions for inducing Treg phenotype (154). These facts possibly indicate that E2 inhibition is an important antitumor strategy for manipulating the tumor microenvironment through inhibiting the function and number of Tregs; additionally, letrozole might also be useful in combination treatments in patients with ERnegative tumors regardless of ER expression in the tumor cells. Returning to the fact that this hormone can inhibit NK activity, an interesting work reported that post-menopausal 
TABLE 1 | Estradiol effects of different immune cells.

\begin{tabular}{|c|c|c|}
\hline Type of immune cells & Modulation & Reference \\
\hline DCs & $\begin{array}{l}\text { Increase expression of co-stimulatory molecules such as INF- } \gamma \\
\text { Stimulation of T-cell proliferation and differentiation } \\
\text { Induction of pro-inflammatory cytokines and chemokines; TNF } \alpha, \mathrm{LL}-2, \mathrm{IL}-6, \mathrm{IL}-10, \mathrm{IL}-8, \mathrm{MCP}-1 \\
\mathrm{DCs} \text { migratory response to lymph nodes after LPS stimulation } \\
\text { Induction of DC differentiation via GM-CSF and the IRF4 } \\
\text { Generation of tolerogenic DCs affecting their cell antigen presenting function }\end{array}$ & $(39-47)$ \\
\hline Neutrophils & $\begin{array}{l}\text { Enhance NO production and the neuronal nitric oxide synthase } \\
\text { Promote neutrophil pro-inflammatory phenotype through GPER- CAMP/PKA/CREB, MAPK activation } \\
\text { Increase IL-1 } 1 \text {, IL-8, PTGS2, SOCS3, and G-CSF gene expression } \\
\text { Increase IL-8 release via G1/GPER } \\
\text { Up-regulation of two markers of neutrophil activation (CD11b and CD62L) } \\
\text { Reduce IL-8 neutrophil release and CD62L expression via ER } \alpha \\
\text { Reduce neutrophil chemotaxis and superoxide anion production } \\
\text { Increase the number of neutrophils in different lymphoid tissues and the NSPs including NE, PR3, and CG } \\
\text { Increase MPO expression }\end{array}$ & $(100-114)$ \\
\hline NK cells & $\begin{array}{l}\text { Reduction of NK cells' cytotoxic activity over long period of exposure } \\
\text { Enhancement of tumor susceptibility and metastasis } \\
\text { Stimulation of NK cell activity in short period of exposure } \\
\text { Induction of PI-9 }\end{array}$ & $(118-126)$ \\
\hline Tregs & $\begin{array}{l}\text { Induction of FoxP3 and IL-10 gene expression } \\
\text { Maintenance of Tregs phenotype } \\
\text { Activation of FoxP3 activity via estradiol-ER } \alpha \text {-EREs } \\
\text { Induction of FoxP3, PD-1, and CTLA-4 protein expression via GPER } \\
\text { Increase of immuno-modulatory cytokines such as TGF- } \beta \text { and IL-10 }\end{array}$ & $(153-160)$ \\
\hline
\end{tabular}

stage I breast cancer patients who received tamoxifen for 1 month showed a statistically significant increase in NK activity; however, NK activity could not be related to ER expression in breast tumors due to the limited number of patients included (164). This fact correlates with mice models and estrogen actions in NK cell activation (124). It is also important to mention that some studies have reported a low proportion of NK cells in late stages of breast tumors (165); therefore, the work of Berry et al. suggests that in the early stages of breast cancer, patients treated with tamoxifen could benefit from the activation of NK cells instead of using this drug in the late stages, concluding that these cells could be considered as therapeutic targets.

With respect to E2 modulation on the TAMs' function, there are not any reports that have evaluated its inhibition effect in clinical trials. We described before that E2 promotes alternative macrophage activation $(72,74)$. Interestingly, Hollmén et al. found that ER-positive and ER-negative tumors induced different macrophage phenotypes with different biological functions, morphology, and cytokine and chemokine secretion. In fact, alternatively activated macrophages present in triple negative breast cancer have a down-regulation in citrulline metabolism 
(80). From this concept, it would be interesting to study the effects of this hormone on citrulline metabolism, since it is known that nitric oxide synthase (iNOS) expression is enhanced by E2 action (166) and, simultaneously, this enzyme is associated with citrulline and arginine metabolism, determining the macrophages' activation phenotype in breast cancer (167). The number of neutrophils in situ in breast tumors is positively correlated with poor prognosis (102), so the modulation of their number could be interesting for breast cancer patients. In 2017, Dai et al. clearly demonstrated that estradiol treatment increased the number of neutrophils in the spleens of mice (105). An increased neutrophil number was also found in the complete blood of prostate cancer patients treated with estramustine (168), an antineoplastic agent with ER affinity (169). However, at present there are not any reports on neutrophil modulation in breast cancer tumors by ER inhibitors. On the other hand, it is known that in neutrophils, NETs formation is relevant for pathogen death, and a selective estrogen receptor modulator (SERM), raloxifene, inhibited NETs formation of human neutrophils, interfering with bacteria clearance after the treatment of the NET inducer phorbol 12-myristate 13acetate (PMA) (170). This was opposite to the effect that was found with tamoxifen treatment (171). With respect to other immune populations, there are not any reports regarding their function modulation by ER inhibitors in breast cancer patients. In addition to the data described above, our workgroup reported that endocrine-disrupting compounds such as bisphenol A (BPA) have a significant effect on the modulation of ER $\alpha$ expression in $\mathrm{T}$ lymphocytes, macrophages, and NK cells of breast cancer tumors as well as in tumor growth. Impressively, a single administration of BPA in neonatal mice resulted in important changes in the presence of Tregs infiltrated into breast tumors in the adult stage (172). These facts provide new approaches to studying the effect of various compounds with estrogenic activity on the modulation of immune cells as well as in the selective inhibition of ER.

On the other hand, although different immunohistochemical studies as well as DNA sequencing data have given promising landscapes of infiltrating immune cells in this neoplasm for its therapy $(13,21)$, and despite the extraordinary efforts to reach a consensus on the study of the invasive population in breast cancer in daily histopathological practice (173, 174), different techniques such as flow cytometry must be applied in the clinic in order to guarantee precise studies. This is because it has been described that, according to the tumor area, the presence of infiltrating lymphocytes can vary (175). The above would allow offering personalized, predictive, and effective combined breast cancer treatments.

\section{CONCLUDING REMARKS AND FUTURE DIRECTIONS}

The main aim of this paper is to stand out the components of immune cells within the tumor microenvironment in different phenotypes of breast cancer, and the participation of E2 and its receptors in their function. As described above, E2 modifies the functions of different immune populations. Although the effects of this hormone were described in a particular way in each immune lineage, it is known that all of them are interconnected by cytokines, maintaining a dynamic interaction in the tumor microenvironment. Several reports have mentioned that immune infiltrating cells play a positive role in avoiding the progression of breast cancer and have a significant clinical impact on the response to treatment in a manner independent of the cancer phenotype $(176,177)$. However, little is known about their percentage and their grade of activation or anergy in different advanced clinic stages of this pathology, which might be modified due to the intratumoral E2 concentration. Based on the role that E2 and its signaling have in different populations of the immune system, we consider it important to evaluate or measure the intratumoral levels of this hormone and/or different compounds such as endocrine disruptors mainly in the advanced stages of this disease, which could be associated with their pro-anergic state. It has been documented that the concentrations of E2 as well as the enzyme that produces it (aromatase) are elevated inside the tumor $(178,179)$, affecting not only epithelial cell growth but also the immune cell effects. Taking into consideration the previous fact, we also regard the use of intratumoral therapy using ER inhibitors in the different types of breast cancer as an integral adjuvant approach for heightening both other therapies and immune response. The previous concept has taken on importance in cancer therapy; indeed, new studies on this topic are being done with different treatment schemes (180). Finally, the immune cells' function and their cytokines are key factors whose modulation should be studied, and they should also be considered as predictive markers and important therapy targets in different subtypes of breast cancer.

\section{AUTHOR CONTRIBUTIONS}

MS-M was in charge of all compilation of information, drafting of the manuscript, and participated in its conception. JM-M participated in the critical revision of the content of the manuscript and made a substantive intellectual contribution to drafting it. All authors read and approved the final manuscript.

\section{FUNDING}

Financial support: Grant IN-209719 from Programa de Apoyo a Proyectos de Investigación e Innovación Tecnológica (PAPIIT), Dirección General de Asuntos del Personal Académico (DGAPA), Universidad Nacional Autónoma de México (UNAM) and Grant 2125 Programa Fronteras en la Ciencia del Consejo Nacional de Ciencia y Tecnología (CONACYT) both to JM-M. MS-M receives a Post-Doctoral fellowship from DGAPA, UNAM. 


\section{REFERENCES}

1. Ahn SG, Kim SJ, Kim C, Jeong J. Molecular classification of triple-negative breast cancer. J Breast Cancer. (2016) 19:223-30. doi: 10.4048/jbc.2016.19.3.223

2. Onland-Moret NC, Kaaks R, van Noord PA, Rinaldi S, Key T, Grobbee DE, et al. Urinary endogenous sex hormone levels and the risk of postmenopausal breast cancer. Br J Cancer. (2003) 88:1394-9. doi: 10.1038/sj.bjc.6600890

3. Coughlin SS, Ekwueme DU. Breast cancer as a global health concern. Cancer Epidemiol. (2009) 33:315-8. doi: 10.1016/j.canep.2009.10.003

4. Schnitt SJ. Classification and prognosis of invasive breast cancer: from morphology to molecular taxonomy. Mod Pathol. (2010) 23(Suppl. 2):S6064. doi: 10.1038/modpathol.2010.33

5. Polyak K. Heterogeneity in breast cancer. J Clin Invest. (2011) 121:3786-8. doi: 10.1172/JCI60534

6. Esquivel-Velazquez M, Ostoa-Saloma P, Palacios-Arreola MI, Nava-Castro KE, Castro JI, Morales-Montor J. The role of cytokines in breast cancer development and progression. I Interferon Cytokine Res. (2015) 35:1-16. doi: 10.1089/jir.2014.0026

7. Bates GJ, Fox SB, Han C, Leek RD, Garcia JF, Harris AL, et al. Quantification of regulatory $\mathrm{T}$ cells enables the identification of high-risk breast cancer patients and those at risk of late relapse. J Clin Oncol. (2006) 24:5373-80. doi: 10.1200/JCO.2006.05.9584

8. Wang M, Zhang C, Song Y, Wang Z, Wang Y, Luo F, et al. Mechanism of immune evasion in breast cancer. Onco Targets Ther. (2017) 10:1561-73. doi: 10.2147/OTT.S126424

9. Glajcar A, Szpor J, Pacek A, Tyrak KE, Chan F, Streb J, et al. The relationship between breast cancer molecular subtypes and mast cell populations in tumor microenvironment. Virchows Arch. (2017) 470:505-15. doi: 10.1007/s00428-017-2103-5

10. Aponte-Lopez A, Fuentes-Panana EM, Cortes-Munoz D, Munoz-Cruz S. Mast cell, the neglected member of the tumor microenvironment: role in breast cancer. J Immunol Res. (2018) 2018:2584243. doi: $10.1155 / 2018 / 2584243$

11. Sica A, Larghi P, Mancino A, Rubino L, Porta C, Totaro MG, et al. Macrophage polarization in tumour progression. Semin Cancer Biol. (2008) 18:349-55. doi: 10.1016/j.semcancer.2008.03.004

12. de Kruijf EM, Sajet A, van Nes JG, Putter H, Smit VT, Eagle RA, et al. NKG2D ligand tumor expression and association with clinical outcome in early breast cancer patients: an observational study. BMC Cancer. (2012) 12:24. doi: 10.1186/1471-2407-12-24

13. Hammerl D, Smid M, TimmermansAM, SleijferS, Martens JWM, Debets R. Breast cancer genomics and immuno-oncological markers to guide immune therapies. Semin Cancer Biol. (2018) 52(Pt 2):178-88. doi: 10.1016/j.semcancer.2017.11.003

14. Ali HR, Chlon L, Pharoah PD, Markowetz F, Caldas C. Patterns of immune infiltration in breast cancer and their clinical implications: a gene-expression-based retrospective study. PLoS Med. (2016) 13:e1002194. doi: 10.1371/journal.pmed.1002194

15. Denkert C, Loibl S, Noske A, Roller M, Muller BM, Komor M, et al. Tumor-associated lymphocytes as an independent predictor of response to neoadjuvant chemotherapy in breast cancer. J Clin Oncol. (2010) 28:105-13. doi: 10.1200/JCO.2009.23.7370

16. Watanabe MA, Oda JM, Amarante MK, Cesar Voltarelli J. Regulatory T cells and breast cancer: implications for immunopathogenesis. Cancer Metastasis Rev. (2010) 29:569-79. doi: 10.1007/s10555-010-9247-y

17. Mahmoud SM, Paish EC, Powe DG, Macmillan RD, Grainge MJ, Lee AH, et al. Tumor-infiltrating CD8+ lymphocytes predict clinical outcome in breast cancer. J Clin Oncol. (2011) 29:1949-55. doi: 10.1200/JCO.2010.30.5037

18. Medrek C, Ponten F, Jirstrom K, Leandersson K. The presence of tumor associated macrophages in tumor stroma as a prognostic marker for breast cancer patients. BMC Cancer. (2012) 12:306. doi: 10.1186/1471-2407-12-306

19. Ali HR, Provenzano E, Dawson SJ, Blows FM, Liu B, Shah M, et al. Association between CD8+ T-cell infiltration and breast cancer survival in 12,439 patients. Ann Oncol. (2014) 25:1536-43. doi: 10.1093/annonc/mdu191

20. Svensson S, Abrahamsson A, Rodriguez GV, Olsson AK, Jensen L, Cao $\mathrm{Y}$, et al. CCL2 and CCL5 are novel therapeutic targets for estrogen-dependent breast cancer. Clin Cancer Res. (2015) 21:3794-805. doi: 10.1158/1078-0432.CCR-15-0204

21. Dieci MV, Tsvetkova V, Orvieto E, Piacentini F, Ficarra G, Griguolo $G$, et al. Immune characterization of breast cancer metastases: prognostic implications. Breast Cancer Res. (2018) 20:62. doi: 10.1186/s13058-018-1003-1

22. Ma C, Zhang Q, Ye J, Wang F, Zhang Y, Wevers E, et al. Tumorinfiltrating gammadelta $\mathrm{T}$ lymphocytes predict clinical outcome in human breast cancer. I Immunol. (2012) 189:5029-36. doi: 10.4049/jimmunol.12 01892

23. Ethier JL, Desautels D, Templeton A, Shah PS, Amir E. Prognostic role of neutrophil-to-lymphocyte ratio in breast cancer: a systematic review and meta-analysis. Breast Cancer Res. (2017) 19:2. doi: 10.1186/s13058-016-0794-1

24. Ascenzi P, Bocedi A, Marino M. Structure-function relationship of estrogen receptor alpha and beta: impact on human health. Mol Aspects Med. (2006) 27:299-402. doi: 10.1016/j.mam.2006.07.001

25. Albanito L, Sisci D, Aquila S, Brunelli E, Vivacqua A, Madeo A, et al. Epidermal growth factor induces $G$ protein-coupled receptor 30 expression in estrogen receptor-negative breast cancer cells. Endocrinology. (2008) 149:3799-808. doi: 10.1210/en.2008-0117

26. Ruan SQ, Wang SW, Wang ZH, Zhang SZ. Regulation of HRGbetal-induced proliferation, migration and invasion of MCF-7 cells by upregulation of GPR30 expression. Mol Med Rep. (2012) 6:131-8. doi: $10.3892 / \mathrm{mmr} .2012 .874$

27. Prossnitz ER, Arterburn JB. International union of basic and clinical pharmacology. XCVII G Protein-coupled estrogen receptor and its pharmacologic modulators. Pharmacol Rev. (2015) 67:505-40. doi: 10.1124/pr.114.009712

28. Evans NJ, Bayliss AL, Reale V, Evans PD. Characterisation of signalling by the endogenous GPER1 (GPR30) Receptor in an embryonic mouse hippocampal cell line (mHippoE-18). PLoS ONE. (2016) 11:e0152138. doi: 10.1371/journal.pone.0152138

29. Frasor J, Danes JM, Komm B, Chang KC, Lyttle CR, Katzenellenbogen BS. Profiling of estrogen up- and down-regulated gene expression in human breast cancer cells: insights into gene networks and pathways underlying estrogenic control of proliferation and cell phenotype. Endocrinology. (2003) 144:4562-74. doi: 10.1210/en.2003-0567

30. Strom A, Hartman J, Foster JS, Kietz S, Wimalasena J, Gustafsson JA. Estrogen receptor beta inhibits 17beta-estradiol-stimulated proliferation of the breast cancer cell line T47D. Proc Natl Acad Sci USA. (2004) 101:1566-71. doi: 10.1073/pnas.0308319100

31. Nutter LM, Wu YY, Ngo EO, Sierra EE, Gutierrez PL, Abul-Hajj YJ. An oquinone form of estrogen produces free radicals in human breast cancer cells: correlation with DNA damage. Chem Res Toxicol. (1994) 7:23-8. doi: 10.1021/tx00037a004

32. Mobley JA, Brueggemeier RW. Estrogen receptor-mediated regulation of oxidative stress and DNA damage in breast cancer. Carcinogenesis. (2004) 25:3-9. doi: 10.1093/carcin/bgg175

33. Cavalieri EL, Rogan EG. Unbalanced metabolism of endogenous estrogens in the etiology and prevention of human cancer. J Steroid Biochem Mol Biol. (2011) 125:169-80. doi: 10.1016/j.jsbmb.2011.03.008

34. Elkin M, Orgel A, Kleinman HK. An angiogenic switch in breast cancer involves estrogen and soluble vascular endothelial growth factor receptor 1. J Natl Cancer Inst. (2004) 96:875-8. doi: 10.1093/jnci/djh140

35. Chaudhary S, Madhukrishna B, Adhya AK, Keshari S, Mishra SK. Overexpression of caspase 7 is ERalpha dependent to affect proliferation and cell growth in breast cancer cells by targeting p21(Cip). Oncogenesis. (2016) 5:e219. doi: 10.1038/oncsis.2016.12

36. Lannigan DA. Estrogen receptor phosphorylation. Steroids. (2003) 68:1-9. doi: 10.1016/S0039-128X(02)00110-1

37. Cunningham M, Gilkeson G. Estrogen receptors in immunity and autoimmunity. Clin Rev Allergy Immunol. (2011) 40:66-73. doi: 10.1007/s12016-010-8203-5

38. Khan D, Ansar Ahmed S. The immune system is a natural target for estrogen action: opposing effects of estrogen in two prototypical autoimmune diseases. Front Immunol. (2015) 6:635. doi: 10.3389/fimmu.2015. 00635 
39. Kovats S. Estrogen receptors regulate innate immune cells and signaling pathways. Cell Immunol. (2015) 294:63-9. doi: 10.1016/j.cellimm.2015.01.018

40. Bengtsson AK, Ryan EJ, Giordano D, Magaletti DM, Clark EA. 17betaestradiol (E2) modulates cytokine and chemokine expression in human monocyte-derived dendritic cells. Blood. (2004) 104:1404-10. doi: 10.1182/blood-2003-10-3380

41. Liu HY, Buenafe AC, Matejuk A, Ito A, Zamora A, Dwyer J, et al. Estrogen inhibition of EAE involves effects on dendritic cell function. J Neurosci Res. (2002) 70:238-48. doi: 10.1002/jnr.10409

42. Paharkova-Vatchkova V, Maldonado R, Kovats S. Estrogen preferentially promotes the differentiation of $\mathrm{CD} 11 \mathrm{c}+\mathrm{CD} 11 \mathrm{~b}$ (intermediate) dendritic cells from bone marrow precursors. J Immunol. (2004) 172:1426-36. doi: 10.4049/jimmunol.172.3.1426

43. Mao A, Paharkova-Vatchkova V, Hardy J, Miller MM, Kovats S. Estrogen selectively promotes the differentiation of dendritic cells with characteristics of Langerhans cells. J Immunol. (2005) 175:5146-51. doi: 10.4049/jimmunol.175.8.5146

44. Nalbandian G, Paharkova-Vatchkova V, Mao A, Nale S, Kovats S. The selective estrogen receptor modulators, tamoxifen and raloxifene, impair dendritic cell differentiation and activation. J Immunol. (2005) 175:2666-75. doi: 10.4049/jimmunol.175.4.2666

45. Carreras E, Turner S, Frank MB, Knowlton N, Osban J, Centola M, et al. Estrogen receptor signaling promotes dendritic cell differentiation by increasing expression of the transcription factor IRF4. Blood. (2010) 115:238-46. doi: 10.1182/blood-2009-08-236935

46. Zhang J, Ye ZW, Chen W, Manevich Y, Mehrotra S, Ball LE, et al. SGlutathionylation of estrogen receptor alpha affects dendritic cell function. $J$ Biol Chem. (2018) 293:4366-80. doi: 10.1074/jbc.M117.814327

47. Papenfuss TL, Powell ND, McClain MA, Bedarf A, Singh A, Gienapp IE, et al. Estriol generates tolerogenic dendritic cells in vivo that protect against autoimmunity. J Immunol. (2011) 186:3346-55. doi: 10.4049/jimmunol.1001322

48. Mantovani A, Sozzani S, Locati M, Allavena P, Sica A. Macrophage polarization: tumor-associated macrophages as a paradigm for polarized M2 mononuclear phagocytes. Trends Immunol. (2002) 23:549-55. doi: 10.1016/S1471-4906(02)02302-5

49. Weusten JJ, Blankenstein MA, Gmelig-Meyling FH, Schuurman HJ, Kater L, Thijssen JH. Presence of oestrogen receptors in human blood mononuclear cells and thymocytes. Acta Endocrinol. (1986) 112:409-14. doi: 10.1530/acta.0.1120409

50. Murphy AJ, Guyre PM, Wira CR, Pioli PA. Estradiol regulates expression of estrogen receptor ERalpha46 in human macrophages. PLoS ONE. (2009) 4:e5539. doi: 10.1371/journal.pone.0005539

51. Mor G, Sapi E, Abrahams VM, Rutherford T, Song J, Hao XY, et al. Interaction of the estrogen receptors with the Fas ligand promoter in human monocytes. J Immunol. (2003) 170:114-22. doi: 10.4049/jimmunol.170.1.114

52. Harkonen PL, Vaananen HK. Monocyte-macrophage system as a target for estrogen and selective estrogen receptor modulators. Ann N Y Acad Sci. (2006) 1089:218-27. doi: 10.1196/annals.1386.045

53. MacMicking J, Xie QW, Nathan C. Nitric oxide and macrophage function. Annu Rev Immunol. (1997) 15:323-50. doi: 10.1146/annurev.immunol.15.1.323

54. Stefano GB, Prevot V, Beauvillain JC, Fimiani C, Welters I, Cadet P, et al. Estradiol coupling to human monocyte nitric oxide release is dependent on intracellular calcium transients: evidence for an estrogen surface receptor. $J$ Immunol. (1999) 163:3758-63.

55. Azenabor AA, Yang S, Job G, Adedokun OO. Expression of iNOS gene in macrophages stimulated with 17beta-estradiol is regulated by free intracellular $\mathrm{Ca}^{2+}$. Biochem Cell Biol. (2004) 82:381-90. doi: 10.1139/o04-032

56. Curuvija I, Stanojevic S, Arsenovic-Ranin N, Blagojevic V, Dimitrijevic $M$, Vidic-Dankovic B, et al. Sex differences in macrophage functions in middle-aged rats: relevance of estradiol level and macrophage estrogen receptor expression. Inflammation. (2017) 40:1087-101. doi: $10.1007 / \mathrm{s} 10753-017-0551-3$
57. Netea-Maier RT, Smit JWA, Netea MG. Metabolic changes in tumor cells and tumor-associated macrophages: a mutual relationship. Cancer Lett. (2018) 413:102-9. doi: 10.1016/j.canlet.2017.10.037

58. Lu B, Jiang YJ, Choy PC. 17-Beta estradiol enhances prostaglandin E2 production in human U937-derived macrophages. Mol Cell Biochem. (2004) 262:101-10. doi: 10.1023/B:MCBI.0000038222.08915.84

59. Tan HY, Wang N, Li S, Hong M, Wang X, Feng Y. The reactive oxygen species in macrophage polarization: reflecting its dual role in progression and treatment of human diseases. Oxid Med Cell Longev. (2016) 2016:2795090. doi: $10.1155 / 2016 / 2795090$

60. Azevedo RB, Lacava ZG, Miyasaka CK, Chaves SB, Curi R. Regulation of antioxidant enzyme activities in male and female rat macrophages by sex steroids. Braz J Med Biol Res. (2001) 34:683-7. doi: $10.1590 /$ S0100-879X2001000500018

61. Vegeto E, Ghisletti S, Meda C, Etteri S, Belcredito S, Maggi A. Regulation of the lipopolysaccharide signal transduction pathway by 17beta-estradiol in macrophage cells. J Steroid Biochem Mol Biol. (2004) 91:59-66. doi: 10.1016/j.jsbmb.2004.02.004

62. Subramanian M, Shaha C. Up-regulation of Bcl-2 through ERK phosphorylation is associated with human macrophage survival in an estrogen microenvironment. J Immunol. (2007) 179:2330-8. doi: 10.4049/jimmunol.179.4.2330

63. Subramanian M, Shaha C. Oestrogen modulates human macrophage apoptosis via differential signalling through oestrogen receptor-alpha and beta. J Cell Mol Med. (2009) 13:2317-29. doi: 10.1111/j.1582-4934.2009.00679.x

64. Takeda K, Akira S. Toll-like receptors in innate immunity. Int Immunol. (2005) 17:1-14. doi: 10.1093/intimm/dxh186

65. Pioli PA, Jensen AL, Weaver LK, Amiel E, Shen Z, Shen L, et al. Estradiol attenuates lipopolysaccharide-induced CXC chemokine ligand 8 production by human peripheral blood monocytes. J Immunol. (2007) 179:6284-90. doi: 10.4049/jimmunol.179.9.6284

66. Turner MD, Nedjai B, Hurst T, Pennington DJ. Cytokines and chemokines: at the crossroads of cell signalling and inflammatory disease. Biochim Biophys Acta. (2014) 1843:2563-82. doi: 10.1016/j.bbamcr.2014.05.014

67. Ralston SH, Russell RG, Gowen M. Estrogen inhibits release of tumor necrosis factor from peripheral blood mononuclear cells in postmenopausal women. J Bone Miner Res. (1990) 5:983-8. doi: 10.1002/jbmr.5650050912

68. Lin SC, Yamate T, Taguchi Y, Borba VZ, Girasole G, O’Brien CA, et al. Regulation of the gp 80 and gp130 subunits of the IL- 6 receptor by sex steroids in the murine bone marrow. J Clin Invest. (1997) 100:1980-90. doi: 10.1172/JCI119729

69. Rogers A, Eastell R. The effect of 17beta-estradiol on production of cytokines in cultures of peripheral blood. Bone. (2001) 29:30-4. doi: 10.1016/S8756-3282(01)00468-9

70. Kramer PR, Kramer SF, Guan G. 17 beta-estradiol regulates cytokine release through modulation of $\mathrm{CD} 16$ expression in monocytes and monocyte-derived macrophages. Arthritis Rheum. (2004) 50:1967-75. doi: 10.1002/art.20309

71. Srivastava S, Weitzmann MN, Cenci S, Ross FP, Adler S, Pacifici R. Estrogen decreases TNF gene expression by blocking JNK activity and the resulting production of c-Jun and JunD. J Clin Invest. (1999) 104:503-13. doi: 10.1172/JCI7094

72. Routley CE, Ashcroft GS. Effect of estrogen and progesterone on macrophage activation during wound healing. Wound Repair Regen. (2009) 17:42-50. doi: $10.1111 / j .1524-475 X .2008 .00440 . x$

73. Mosser DM, Edwards JP. Exploring the full spectrum of macrophage activation. Nat Rev Immunol. (2008) 8:958-69. doi: 10.1038/nri2448

74. Campbell L, Emmerson E, Williams H, Saville CR, Krust A, Chambon P, et al. Estrogen receptor-alpha promotes alternative macrophage activation during cutaneous repair. J Invest Dermatol. (2014) 134:2447-57. doi: 10.1038/jid.2014.175

75. Toniolo A, Fadini GP, Tedesco S, Cappellari R, Vegeto E, Maggi A, et al. Alternative activation of human macrophages is rescued by estrogen treatment in vitro and impaired by menopausal status. J Clin Endocrinol Metab. (2015) 100:E50-8. doi: 10.1210/jc.2014-2751 
76. Leek RD, Lewis CE, Whitehouse R, Greenall M, Clarke J, Harris AL. Association of macrophage infiltration with angiogenesis and prognosis in invasive breast carcinoma. Cancer. Res. (1996) 56:4625-9.

77. Hanada T, Nakagawa M, Emoto A, Nomura T, Nasu N, Nomura Y. Prognostic value of tumor-associated macrophage count in human bladder cancer. Int J Urol. (2000) 7:263-9. doi: 10.1046/j.1442-2042.2000.00190.x

78. Lissbrant IF, Stattin P, Wikstrom P, Damber JE, Egevad L, Bergh A. Tumor associated macrophages in human prostate cancer: relation to clinicopathological variables and survival. Int J Oncol. (2000) 17:445-51. doi: 10.3892/ijo.17.3.445

79. Erreni M, Mantovani A, Allavena P. Tumor-associated Macrophages (TAM) and Inflammation in Colorectal Cancer. Cancer Microenviron. (2011) 4:14154. doi: 10.1007/s12307-010-0052-5

80. Hollmen M, Roudnicky F, Karaman S, Detmar M. Characterization of macrophage-cancer cell crosstalk in estrogen receptor positive and triplenegative breast cancer. Sci Rep. (2015) 5:9188. doi: 10.1038/srep09188

81. Ning C, Xie B, Zhang L, Li C, Shan W, Yang B, et al. Infiltrating macrophages induce ERalpha expression through an IL17A-mediated Epigenetic mechanism to sensitize endometrial cancer cells to estrogen. Cancer Res. (2016) 76:1354-66. doi: 10.1158/0008-5472.CAN-15-1260

82. Krystel-Whittemore M, Dileepan KN, Wood JG. Mast cell: a multi-functional master cell. Front Immunol. (2015) 6:620. doi: 10.3389/fimmu.2015.00620

83. Irani AA, Schechter NM, Craig SS, DeBlois G, Schwartz LB. Two types of human mast cells that have distinct neutral protease compositions. Proc Natl Acad Sci USA. (1986) 83:4464-8. doi: 10.1073/pnas.83.12.4464

84. Cimpean AM, Tamma R, Ruggieri S, Nico B, Toma A, Ribatti D. Mast cells in breast cancer angiogenesis. Crit Rev Oncol Hematol. (2017) 115:23-6. doi: 10.1016/j.critrevonc.2017.04.009

85. Zhao XJ, McKerr G, Dong Z, Higgins CA, Carson J, Yang ZQ, et al. Expression of oestrogen and progesterone receptors by mast cells alone, but not lymphocytes, macrophages or other immune cells in human upper airways. Thorax. (2001) 56:205-11. doi: 10.1136/thorax.56.3.205

86. Jiang YA, Zhang YY, Luo HS, Xing SF. Mast cell density and the context of clinicopathological parameters and expression of p185, estrogen receptor, and proliferating cell nuclear antigen in gastric carcinoma. World $J$ Gastroenterol. (2002) 8:1005-8. doi: 10.3748/wjg.v8.i6.1005

87. Nicovani S, Rudolph MI. Estrogen receptors in mast cells from arterial walls. Biocell. (2002) 26:15-24.

88. Zierau O, Zenclussen AC, Jensen F. Role of female sex hormones, estradiol and progesterone, in mast cell behavior. Front Immunol. (2012) 3:169. doi: 10.3389/fimmu.2012.00169

89. O’Brien E, Dolinoy DC, Mancuso P. Bisphenol A at concentrations relevant to human exposure enhances histamine and cysteinyl leukotriene release from bone marrow-derived mast cells. J Immunotoxicol. (2014) 11:84-9. doi: 10.3109/1547691X.2013.800925

90. Medina V, Croci M, Crescenti E, Mohamad N, Sanchez-Jimenez F, Massari N, et al. The role of histamine in human mammary carcinogenesis: $\mathrm{H} 3$ and H4 receptors as potential therapeutic targets for breast cancer treatment. Cancer Biol Ther. (2008) 7:28-35. doi: 10.4161/cbt.7.1.5123

91. Cocchiara R, Albeggiani G, Di Trapani G, Azzolina A, Lampiasi N, Rizzo F, et al. Oestradiol enhances in vitro the histamine release induced by embryonic histamine-releasing factor (EHRF) from uterine mast cells. Hum Reprod. (1992) 7:1036-41. doi: 10.4161/cbt.7.1.5123

92. Narita S, Goldblum RM, Watson CS, Brooks EG, Estes DM, Curran EM, et al. Environmental estrogens induce mast cell degranulation and enhance IgE-mediated release of allergic mediators. Environ Health Perspect. (2007) 115:48-52. doi: 10.1289/ehp.9378

93. Mangia A, Malfettone A, Rossi R, Paradiso A, Ranieri G, Simone G, et al. Tissue remodelling in breast cancer: human mast cell tryptase as an initiator of myofibroblast differentiation. Histopathology. (2011) 58:1096106. doi: 10.1111/j.1365-2559.2011.03842.x

94. Jensen F, Woudwyk M, Teles A, Woidacki K, Taran F, Costa S, et al. Estradiol and progesterone regulate the migration of mast cells from the periphery to the uterus and induce their maturation and degranulation. PLoS ONE. (2010) 5:e14409. doi: 10.1371/journal.pone.0014409

95. Zaitsu M, Narita S, Lambert KC, Grady JJ, Estes DM, Curran EM, et al. Estradiol activates mast cells via a non-genomic estrogen receptor-alpha and calcium influx. Mol Immunol. (2007) 44:1977-85. doi: 10.1016/j.molimm.2006.09.030

96. Mayadas TN, Cullere X, Lowell CA. The multifaceted functions of neutrophils. Annu Rev Pathol. (2014) 9:181-218. doi: 10.1146/annurev-pathol-020712-164023

97. Rosales C, Demaurex N, Lowell CA, Uribe-Querol E. Neutrophils: their role in innate and adaptive immunity. J Immunol Res. (2016) 2016:1469780. doi: $10.1155 / 2016 / 1469780$

98. Tecchio C, Micheletti A, Cassatella MA. Neutrophil-derived cytokines: facts beyond expression. Front Immunol. (2014) 5:508. doi: 10.3389/fimmu.2014.00508

99. Stygar D, Westlund P, Eriksson H, Sahlin L. Identification of wild type and variants of oestrogen receptors in polymorphonuclear and mononuclear leucocytes. Clin Endocrinol. (2006) 64:74-81. doi: 10.1111/j.1365-2265.2005.02420.x

100. Molloy EJ, O’Neill AJ, Grantham JJ, Sheridan-Pereira M, Fitzpatrick JM, Webb DW, et al. Sex-specific alterations in neutrophil apoptosis: the role of estradiol and progesterone. Blood. (2003) 102:2653-9. doi: 10.1182/blood-2003-02-0649

101. Bain BJ, England JM. Normal haematological values: sex difference in neutrophil count. Br Med J. (1975) 1:306-9. doi: 10.1136/bmj.1.5953.306

102. Duran MG, Galvez GG, de Frutos T, Diaz Recasens J, Casado S, Lopez Farre A. 17 Beta-estradiol-stimulated nitric oxide production by neutrophils: effect on platelet activation. Obstet Gynecol. (2000) 95:284-90. doi: 10.1097/00006250-200002000-00022

103. Molero L, Garcia-Duran M, Diaz-Recasens J, Rico L, Casado S, LopezFarre A. Expression of estrogen receptor subtypes and neuronal nitric oxide synthase in neutrophils from women and men: regulation by estrogen. Cardiovasc Res. (2002) 56:43-51. doi: 10.1016/S0008-6363(02) 00505-9

104. Pham CT. Neutrophil serine proteases fine-tune the inflammatory response. Int J Biochem Cell Biol. (2008) 40:1317-33. doi: 10.1016/j.biocel.2007.11.008

105. Dai R, Cowan C, Heid B, Khan D, Liang Z, Pham CT, et al. Neutrophils and neutrophil serine proteases are increased in the spleens of estrogen-treated C57BL/6 mice and several strains of spontaneous lupus-prone mice. PLoS ONE. (2017) 12:e0172105. doi: 10.1371/journal.pone.0172105

106. Fridlender ZG, Sun J, Kim S, Kapoor V, Cheng G, Ling L, et al. Polarization of tumor-associated neutrophil phenotype by TGF-beta: "N1" versus "N2" TAN. Cancer Cell. (2009) 16:183-94. doi: 10.1016/j.ccr.2009.06.017

107. Rodenas MC, Tamassia N, Cabas I, Calzetti F, Meseguer J, Cassatella MA, et al. $\mathrm{G}$ protein-coupled estrogen receptor 1 regulates human neutrophil functions. Biomedicine Hub. (2017) 2:2-2. doi: 10.1159/000454981

108. Malisorn N, Morales NP, Sanvarinda Y, Wanikiat, P. Characterization of estrogen receptor mediating neutrophil function Thai J Pharmacol. (2010) 32:276-80.

109. Simon SI, Burns AR, Taylor AD, Gopalan PK, Lynam EB, Sklar LA, et al. L-selectin (CD62L) cross-linking signals neutrophil adhesive functions via the Mac-1 (CD11b/CD18) beta 2-integrin. J Immunol. (1995) 155:1 502-14.

110. Bekesi G, Kakucs R, Varbiro S, Racz K, Sprintz D, Feher J, et al. In vitro effects of different steroid hormones on superoxide anion production of human neutrophil granulocytes. Steroids. (2000) 65:889-94. doi: 10.1016/S0039-128X(00)00183-5

111. Bekesi G, Tulassay Z, Racz K, Feher J, Szekacs B, Kakucs R, et al. The effect of estrogens on superoxide anion generation by human neutrophil granulocytes: possible consequences of the antioxidant defense. Gynecol Endocrinol. (2007) 23:451-4. doi: 10.1080/09513590701 483951

112. El-Benna J, Hurtado-Nedelec M, Marzaioli V, Marie JC, GougerotPocidalo MA, Dang PM. Priming of the neutrophil respiratory burst: role in host defense and inflammation. Immunol Rev. (2016) 273:180-93. doi: 10.1111/imr.12447

113. Chung HH, Or YZ, Shrestha S, Loh JT, Lim CL, Ong Z, et al. Estrogen reprograms the activity of neutrophils to foster protumoral microenvironment during mammary involution. Sci Rep. (2017) 7:46485. doi: 10.1038/srep46485

114. Vazquez Rodriguez G, Abrahamsson A, Jensen LD, Dabrosin C. Estradiol promotes breast cancer cell migration via recruitment and 
activation of neutrophils. Cancer Immunol Res. (2017) 5:234-47. doi: 10.1158/2326-6066.CIR-16-0150

115. Vivier E, Tomasello E, Baratin M, Walzer T, Ugolini S. Functions of natural killer cells. Nat Immunol. (2008) 9:503-10. doi: 10.1038/ni1582

116. Garrido F, Cabrera T, Aptsiauri N. "Hard" and "soft" lesions underlying the HLA class I alterations in cancer cells: implications for immunotherapy. Int J Cancer. (2010) 127:249-56. doi: 10.1002/ijc.25270

117. Roberti MP, Mordoh J, Levy EM. Biological role of NK cells and immunotherapeutic approaches in breast cancer. Front Immunol. (2012) 3:375. doi: 10.3389/fimmu. 2012.00375

118. Seaman WE, Gindhart TD. Effect of estrogen on natural killer cells. Arthritis Rheum. (1979) 22:1234-40. doi: 10.1002/art.1780221110

119. Nilsson N, Carlsten H. Estrogen induces suppression of natural killer cell cytotoxicity and augmentation of polyclonal B cell activation. Cell Immunol. (1994) 158:131-9. doi: 10.1006/cimm.1994.1262

120. Albrecht AE, Hartmann BW, Scholten C, Huber JC, Kalinowska W, Zielinski CC. Effect of estrogen replacement therapy on natural killer cell activity in postmenopausal women. Maturitas. (1996) 25:217-22. doi: 10.1016/S0378-5122(96)01063-8

121. Scanlan JM, Werner JJ, Legg RL, Laudenslager ML. Natural killer cell activity is reduced in association with oral contraceptive use. Psychoneuroendocrinology. (1995) 20:281-7. doi: 10.1016/0306-4530(94)00059-J

122. Hanna N, Schneider M. Enhancement of tumor metastasis and suppression of natural killer cell activity by beta-estradiol treatment. I Immunol. (1983) 130:974-80.

123. Kalland T, Forsberg JG. Natural killer cell activity and tumor susceptibility in female mice treated neonatally with diethylstilbestrol. Cancer Res. (1981) 41(12 Pt 1):5134-40.

124. Screpanti I, Santoni A, Gulino A, Herberman RB, Frati L. Estrogen and antiestrogen modulation of the levels of mouse natural killer activity and large granular lymphocytes. Cell Immunol. (1987) 106:191-202.

125. Jiang X, Orr BA, Kranz DM, Shapiro DJ. Estrogen induction of the granzyme $\mathrm{B}$ inhibitor, proteinase inhibitor 9 , protects cells against apoptosis mediated by cytotoxic T lymphocytes and natural killer cells. Endocrinology. (2006) 147:1419-26. doi: 10.1210/en.2005-0996

126. Liu C, Yu S, Zinn K, Wang J, Zhang L, Jia Y, et al. Murine mammary carcinoma exosomes promote tumor growth by suppression of NK cell function. J Immunol. (2006) 176:1375-85. doi: 10.4049/jimmunol.176.3.1375

127. Hoffman W, Lakkis FG, Chalasani G. B cells, antibodies, and more. Clin J Am Soc Nephrol. (2016) 11:137-54. doi: 10.2215/CJN.09430915

128. Grimaldi CM, Cleary J, Dagtas AS, Moussai D, Diamond B. Estrogen alters thresholds for B cell apoptosis and activation. J Clin Invest. (2002) 109:162533. doi: $10.1172 / \mathrm{JCI} 14873$

129. Kanda, N., and Tamaki, K. (1999). Estrogen enhances immunoglobulin production by human PBMCs. J Allergy Clin Immunol. 103(2 Pt 1):282-8. doi: 10.1016/S0091-6749(99)70503-8

130. Paavonen T, Andersson LC, Adlercreutz H. Sex hormone regulation of in vitro immune response. Estradiol enhances human B cell maturation via inhibition of suppressor T cells in pokeweed mitogen-stimulated cultures. J Exp Med. (1981) 154:1935-45. doi: 10.1084/jem.154.6.1935

131. Myers MJ, Petersen BH. Estradiol induced alterations of the immune systemI. Enhancement of IgM production Int J Immunopharmacol. (1985) 7:207-13. doi: 10.1016/0192-0561(85)90028-1

132. Vollmers HP, Brandlein S. Natural antibodies and cancer. $N$ Biotechnol. (2009) 25:294-8. doi: 10.1016/j.nbt.2009.03.016

133. Diaz-Zaragoza M, Hernandez-Avila R, Viedma-Rodriguez R, ArenasAranda D, Ostoa-Saloma P. Natural and adaptive IgM antibodies in the recognition of tumor-associated antigens of breast cancer (Review). Oncol Rep. (2015) 34:1106-14. doi: 10.3892/or.2015.4095

134. Papatestas AE, Bramis J, Aufses AHJr. Serum immunoglobulins in women with breast cancer. J Surg Oncol. (1979) 12:155-63. doi: 10.1002/jso.2930120209

135. Catusse J, Wollner S, Leick M, Schrottner P, Schraufstatter I, Burger M. Attenuation of CXCR4 responses by CCL18 in acute lymphocytic leukemia B cells. J Cell Physiol. (2010) 225:792-800. doi: 10.1002/jcp. 22284
136. Nugent A, Proia RL. The role of $G$ protein-coupled receptors in lymphoid malignancies. Cell Signal. (2017) 39:95-107. doi: 10.1016/j.cellsig.2017.08.002

137. Zhu J, Paul WE. CD4 T cells: fates, functions, and faults. Blood. (2008) 112:1557-69. doi: 10.1182/blood-2008-05-078154

138. Okasha SA, Ryu S, Do Y, McKallip RJ, Nagarkatti M, Nagarkatti PS. Evidence for estradiol-induced apoptosis and dysregulated $\mathrm{T}$ cell maturation in the thymus. Toxicology. (2001) 163:49-62. doi: 10.1016/S0300-483X(01)00374-2

139. Staples JE, Gasiewicz TA, Fiore NC, Lubahn DB, Korach KS, Silverstone AE. Estrogen receptor alpha is necessary in thymic development and estradiolinduced thymic alterations. J Immunol. (1999) 163:4168-74.

140. Erlandsson MC, Ohlsson C, Gustafsson JA, Carlsten H. Role of oestrogen receptors alpha and beta in immune organ development and in oestrogen-mediated effects on thymus. Immunology. (2001) 103:17-25. doi: 10.1046/j.1365-2567.2001.01212.x

141. Lelu K, Laffont S, Delpy L, Paulet PE, Perinat T, Tschanz SA, et al. Estrogen receptor alpha signaling in $\mathrm{T}$ lymphocytes is required for estradiol-mediated inhibition of Th1 and Th17 cell differentiation and protection against experimental autoimmune encephalomyelitis. J Immunol. (2011) 187:238693. doi: 10.4049/jimmunol.1101578

142. Michalek RD, Gerriets VA, Jacobs SR, Macintyre AN, MacIver NJ, Mason EF, et al. Cutting edge: distinct glycolytic and lipid oxidative metabolic programs are essential for effector and regulatory CD4+ T cell subsets. J Immunol. (2011) 186:3299-303. doi: 10.4049/jimmunol.1003613

143. Michalek RD, Gerriets VA, Nichols AG, Inoue M, Kazmin D, Chang CY, et al. Estrogen-related receptor-alpha is a metabolic regulator of effector T-cell activation and differentiation. Proc Natl Acad Sci USA. (2011) 108:18348-53. doi: 10.1073/pnas.1108856108

144. Grasso G, Muscettola $M$. The influence of beta-estradiol and progesterone on interferon gamma production in vitro. Int J Neurosci. (1990) 51:315-7. doi: $10.3109 / 00207459008999730$

145. Karpuzoglu-Sahin E, Hissong BD, Ansar Ahmed S. Interferon-gamma levels are upregulated by 17-beta-estradiol and diethylstilbestrol. J Reprod Immunol. (2001) 52:113-27. doi: 10.1016/S0165-0378(01)00117-6

146. Salem ML. Estrogen, a double-edged sword: modulation of TH1- and TH2-mediated inflammations by differential regulation of TH1/TH2 cytokine production. Curr Drug Targets Inflamm Allergy. (2004) 3:97-104. doi: $10.2174 / 1568010043483944$

147. Malutan AM, Dan M, Nicolae C, Carmen M. Proinflammatory and antiinflammatory cytokine changes related to menopause. Prz Menopauzalny. (2014) 13:162-8. doi: 10.5114/pm.2014.43818

148. Kamada M, Irahara M, Maegawa M, Ohmoto Y, Murata K, Yasui T, et al. Transient increase in the levels of T-helper 1 cytokines in postmenopausal women and the effects of hormone replacement therapy. Gynecol Obstet Invest. (2001) 52:82-8. doi: 10.1159/000052948

149. Salem ML, Matsuzaki G, Madkour GA, Nomoto K. Beta-estradiol-induced decrease in IL-12 and TNF-alpha expression suppresses macrophage functions in the course of Listeria monocytogenes infection in mice. Int J Immunopharmacol. (1999) 21:481-97. doi: 10.1016/S0192-0561(99)0 0027-2

150. Lambert KC, Curran EM, Judy BM, Milligan GN, Lubahn DB, Estes DM. Estrogen receptor alpha (ERalpha) deficiency in macrophages results in increased stimulation of $\mathrm{CD} 4+\mathrm{T}$ cells while 17beta-estradiol acts through ERalpha to increase IL-4 and GATA-3 expression in CD4+ T cells independent of antigen presentation. J Immunol. (2005) 175:5716-23. doi: 10.4049/jimmunol.175.9.5716

151. Sakaguchi S, Ono M, Setoguchi R, Yagi H, Hori S, Fehervari Z, et al. Foxp3+ $\mathrm{CD} 25+\mathrm{CD} 4+$ natural regulatory $\mathrm{T}$ cells in dominant self-tolerance and autoimmune disease. Immunol Rev. (2006) 212:8-27. doi: $10.1111 / j .0105-2896.2006 .00427 . x$

152. Chaudhary B, Elkord, E. Regulatory T cells in the tumor microenvironment and cancer progression: role and therapeutic targeting. Vaccines. (2016) 4:E28. doi: $10.3390 /$ vaccines4030028.

153. Polanczyk MJ, Carson BD, Subramanian S, Afentoulis M, Vandenbark AA, Ziegler SF, et al. Cutting edge: estrogen drives expansion of the CD4+CD25+ regulatory T cell compartment. J Immunol. (2004) 173:222730. doi: 10.4049/jimmunol.173.4.2227 
154. Tai P, Wang J, Jin H, Song X, Yan J, Kang Y, et al. Induction of regulatory T cells by physiological level estrogen. J Cell Physiol. (2008) 214:456-64. doi: $10.1002 /$ jcp. 21221

155. Polanczyk MJ, Hopke C, Vandenbark AA, Offner H. Treg suppressive activity involves estrogen-dependent expression of programmed death-1 (PD-1). Int Immunol. (2007) 19:337-43. doi: 10.1093/intimm/dxl151

156. Prieto GA, Rosenstein Y. Oestradiol potentiates the suppressive function of human CD4 CD25 regulatory $\mathrm{T}$ cells by promoting their proliferation. Immunology. (2006) 118:58-65. doi: 10.1111/j.1365-2567.2006.02339.x

157. Adurthi S, Kumar MM, Vinodkumar HS, Mukherjee G, Krishnamurthy H, Acharya KK, et al. Oestrogen Receptor-alpha binds the FOXP3 promoter and modulates regulatory T-cell function in human cervical cancer. Sci Rep. (2017) 7:17289. doi: 10.1038/s41598-017-17102-w

158. Brunsing RL, Owens KS, Prossnitz ER. The G protein-coupled estrogen receptor (GPER) agonist G-1 expands the regulatory T-cell population under TH17-polarizing conditions. J Immunother. (2013) 36:190-6. doi: 10.1097/CJI.0b013e31828d8e3b

159. Askenasy N, Kaminitz A, Yarkoni S. Mechanisms of $\mathrm{T}$ regulatory cell function. Autoimmun Rev. (2008) 7:370-5. doi: 10.1016/j.autrev.2008.03.001

160. Luo CY, Wang L, Sun C, Li DJ. Estrogen enhances the functions of $\mathrm{CD} 4(+) \mathrm{CD} 25(+)$ Foxp3(+) regulatory $\mathrm{T}$ cells that suppress osteoclast differentiation and bone resorption in vitro. Cell Mol Immunol. (2011) 8:50-8. doi: $10.1038 / \mathrm{cmi} .2010 .54$

161. Tong CWS, Wu M, Cho WCS, To KKW. Recent advances in the treatment of breast cancer. Front Oncol. (2018) 8:227. doi: 10.3389/fonc.2018.00227

162. Li Z, Dong P, Ren M, Song Y, Qian X, Yang Y, et al. PD-L1 Expression is associated with tumor FOXP3 $(+)$ regulatory T-cell infiltration of breast cancer and poor prognosis of patient. J Cancer. (2016) 7:784-93. doi: $10.7150 /$ jca. 14549

163. Generali D, Bates G, Berruti A, Brizzi MP, Campo L, Bonardi S, et al. Immunomodulation of FOXP3 + regulatory $\mathrm{T}$ cells by the aromatase inhibitor letrozole in breast cancer patients. Clin Cancer Res. (2009) 15:104651. doi: 10.1158/1078-0432.CCR-08-1507

164. Berry J, Green BJ, Matheson DS. Modulation of natural killer cell activity by tamoxifen in stage I post-menopausal breast cancer. Eur J Cancer Clin Oncol. (1987) 23:517-20. doi: 10.1016/0277-5379(87)90313-0

165. Jiang X, Shapiro DJ. The immune system and inflammation in breast cancer. Mol Cell Endocrinol. (2014) 382:673-82. doi: 10.1016/j.mce.2013.06.003

166. Karpuzoglu E, Fenaux JB, Phillips RA, Lengi AJ, Elvinger FO, Ansar Ahmed S. Estrogen Up-Regulates Inducible Nitric Oxide Synthase, Nitric Oxide, and Cyclooxygenase-2 in Splenocytes Activated with T Cell Stimulants: Role of Interferon- $\gamma$. Endocrinology. (2006) 147:662-71. doi: 10.1210/en.2005-0829

167. Rath M, Muller I, Kropf P, Closs EI, Munder M. Metabolism via arginase or nitric oxide synthase: two competing arginine pathways in macrophages. Front Immunol. (2014) 5:532. doi: 10.3389/fimmu.2014.00532

168. Suzuki M, Fujimura T, Enomoto Y, Nishimatsu H, Ishikawa A. 17 $\beta$-Estradiolmediated elevation of peripheral white blood cell count during estramustine phosphate therapy for prostate cancer. Int J Endocrinol Metab. (2011) 9:34751. doi: 10.5812/Kowsar.1726913X.2246

169. Harrison JD, Watson S, Ellis IO, Morris DL. A study on the effects of estradiol and estramustine on gastrointestinal cell lines. Eur J Surg Oncol. (1990) 16:116-20.

170. Flores R, Dohrmann S, Schaal C, Hakkim A, Nizet V, Corriden R. The selective estrogen receptor modulator raloxifene inhibits neutrophil extracellular trap formation. Front Immunol. (2016) 7:566. doi: 10.3389/fimmu.2016.00566

171. Corriden R, Hollands A, Olson J, Derieux J, Lopez J, Chang JT, et al. Tamoxifen augments the innate immune function of neutrophils through modulation of intracellular ceramide. Nat Commun. (2015) 6:8369. doi: $10.1038 /$ ncomms 9369

172. Palacios-Arreola MI, Nava-Castro KE, Rio-Araiza VHD, Perez-Sanchez NY, Morales-Montor J. A single neonatal administration of Bisphenol A induces higher tumour weight associated to changes in tumour microenvironment in the adulthood. Sci Rep. (2017) 7:10573. doi: 10.1038/s41598-01710135-1

173. Denkert C, Wienert S, Poterie A, Loibl S, Budczies J, Badve S, et al. Standardized evaluation of tumor-infiltrating lymphocytes in breast cancer: results of the ring studies of the international immunooncology biomarker working group. Mod Pathol. (2016) 29:1155-64. doi: 10.1038/modpathol.2016.109

174. Yuan Y. Modelling the spatial heterogeneity and molecular correlates of lymphocytic infiltration in triple-negative breast cancer. $J R$ Soc Interface. (2015) 12, 1-13. doi: 10.1098/rsif.2014.1153

175. Savas P, Salgado R, Denkert C, Sotiriou C, Darcy PK, Smyth MJ, et al. Clinical relevance of host immunity in breast cancer: from TILs to the clinic. Nat Rev Clin Oncol. (2016) 13:228-41. doi: 10.1038/nrclinonc. 2015.215

176. Bianchini G, Gianni L. The immune system and response to HER2targeted treatment in breast cancer. Lancet Oncol. (2014) 15:e58-68. doi: 10.1016/S1470-2045(13)70477-7

177. West NR, Milne K, Truong PT, Macpherson N, Nelson BH, Watson PH. Tumor-infiltrating lymphocytes predict response to anthracycline-based chemotherapy in estrogen receptor-negative breast cancer. Breast Cancer Res. (2011) 13:R126. doi: 10.1186/bcr3072

178. Takagi K, Ishida T, Miki Y, Hirakawa H, Kakugawa Y, Amano G, et al. Intratumoral concentration of estrogens and clinicopathological changes in ductal carcinoma in situ following aromatase inhibitor letrozole treatment. Br J Cancer. (2013) 109:100-8. doi: 10.1038/bjc.2013.284

179. Suzuki T, Miki Y, Akahira J, Moriya T, Ohuchi N, Sasano H. Aromatase in human breast carcinoma as a key regulator of intratumoral sex steroid concentrations. Endocr J. (2008) 55:455-63. doi: 10.1507/endocrj. K07E-053

180. Marabelle A, Andtbacka R, Harrington K, Melero I, Leidner R, de Baere $\mathrm{T}$, et al. Starting the fight in the tumor: expert recommendations for the development of human intratumoral immunotherapy (HIT-IT). Ann Oncol. (2018) 29:2163-74. doi: 10.1093/annonc/mdy423

Conflict of Interest Statement: The authors declare that the research was conducted in the absence of any commercial or financial relationships that could be construed as a potential conflict of interest.

Copyright (C) 2019 Segovia-Mendoza and Morales-Montor. This is an open-access article distributed under the terms of the Creative Commons Attribution License (CC $B Y)$. The use, distribution or reproduction in other forums is permitted, provided the original author(s) and the copyright owner(s) are credited and that the original publication in this journal is cited, in accordance with accepted academic practice. No use, distribution or reproduction is permitted which does not comply with these terms. 